San Jose State University

SJSU ScholarWorks

Master's Theses

Master's Theses and Graduate Research

Fall 2009

\title{
Flow cytometric analysis of phytoplankton viability in Elkhorn Slough, California.
}

Sarah Rose Smith

San Jose State University

Follow this and additional works at: https://scholarworks.sjsu.edu/etd_theses

\section{Recommended Citation}

Smith, Sarah Rose, "Flow cytometric analysis of phytoplankton viability in Elkhorn Slough, California."

(2009). Master's Theses. 3970.

DOI: https://doi.org/10.31979/etd.euju-9kgf

https://scholarworks.sjsu.edu/etd_theses/3970

This Thesis is brought to you for free and open access by the Master's Theses and Graduate Research at SJSU ScholarWorks. It has been accepted for inclusion in Master's Theses by an authorized administrator of SJSU ScholarWorks. For more information, please contact scholarworks@sjsu.edu. 


\title{
FLOW CYTOMETRIC ANALYSIS OF PHYTOPLANKTON VIABILITY IN ELKHORN SLOUGH, CALIFORNIA
}

\author{
A Thesis \\ Presented to \\ The Faculty of Moss Landing Marine Laboratories \\ San José State University \\ In Partial Fulfillment \\ of the Requirements for the Degree \\ Master of Science
}

by

Sarah Rose Smith

December 2009 
UMI Number: 1484318

All rights reserved

INFORMATION TO ALL USERS

The quality of this reproduction is dependent upon the quality of the copy submitted.

In the unlikely event that the author did not send a complete manuscript and there are missing pages, these will be noted. Also, if material had to be removed, a note will indicate the deletion.

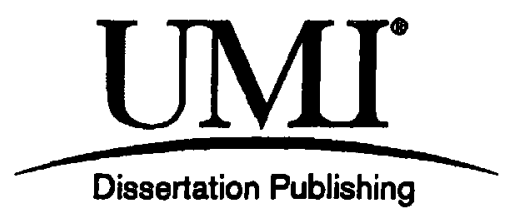

UMI 1484318

Copyright 2010 by ProQuest LLC.

All rights reserved. This edition of the work is protected against unauthorized copying under Title 17, United States Code.

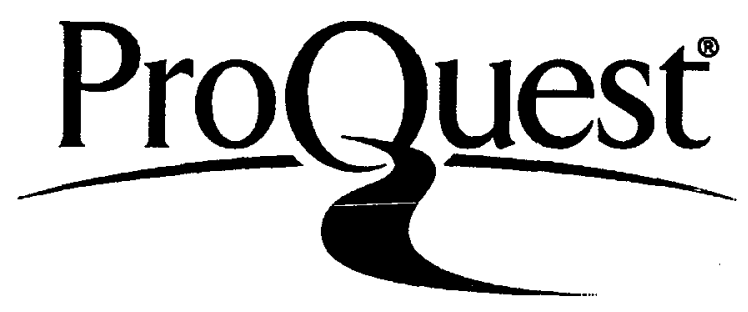

ProQuest LLC

789 East Eisenhower Parkway

P.O. Box 1346

Ann Arbor, Ml 48106-1346 
(C) 2009

Sarah Rose Smith

ALL RIGHTS RESERVED 


\title{
SAN JOSÉ STATE UNIVERSITY
}

The Undersigned Thesis Committee Approves the Thesis Titled

FLOW CYTOMETRIC ANALYSIS OF PHYTOPLANKTON VIABILITY IN ELKHORN SLOUGH, CALIFORNIA

\author{
by \\ Sarah Rose Smith
}

APPROVED FOR MOSS LANDING MARINE LABORATORIES

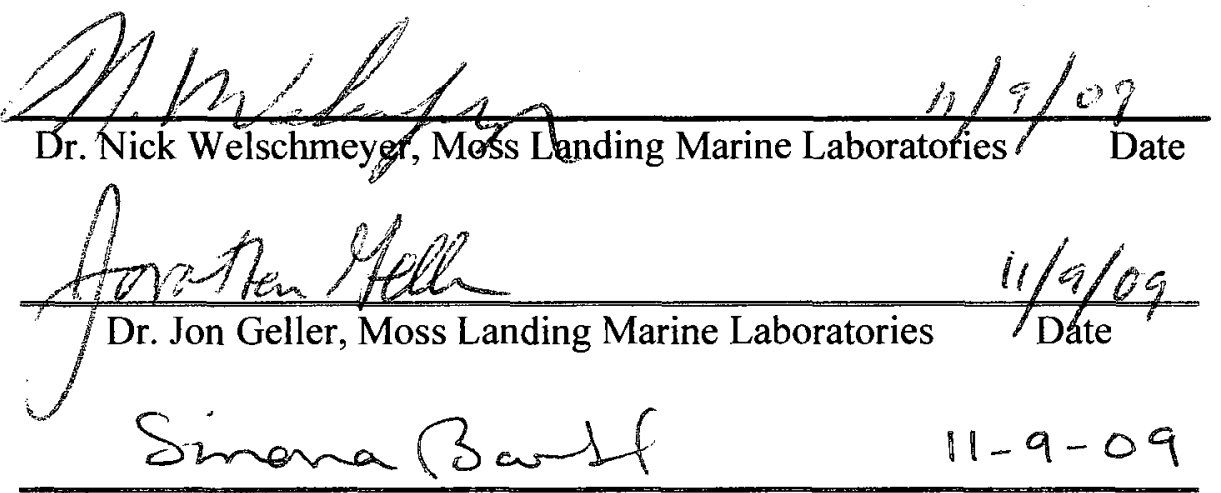

Dr. Simona Bartl, Moss Landing Marine Laboratories Date

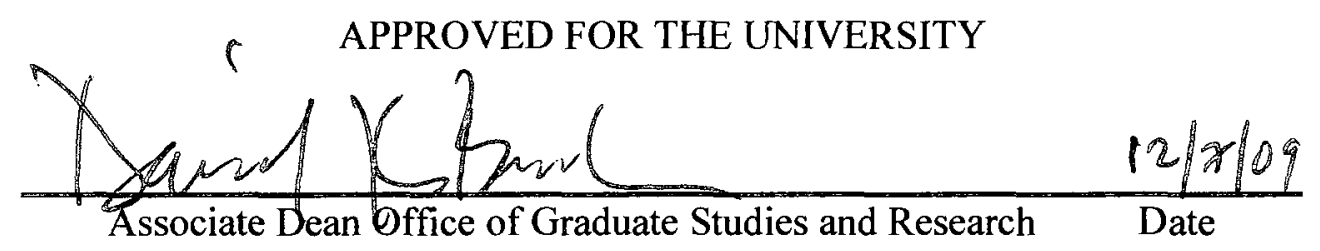




\section{ABSTRACT \\ FLOW CYTOMETRIC ANALYSIS OF PHYTOPLANKTON VIABILITY IN ELKHORN SLOUGH, CALIFORNIA}

by Sarah R. Smith

The phytoplankton community structure of Elkhorn Slough was characterized flow cytometrically and found to be dominated in the upper reaches by small cryptophytes $(<5 \mu \mathrm{m})$ and picoeukaryotic phytoplankton $(<3 \mu \mathrm{m})$. Cell-specific viability of the small cryptophyte population was quantified along a $5 \mathrm{~km}$ transect from the mouth to the shallow upper reaches of Elkhorn Slough using fluorescein diacetate (FDA). Corroborative viability techniques, including SYTOX Green stain and cell digestion assay, were determined to be inappropriate for use in Elkhorn Slough due to indiscriminate staining of suspended particulates and incompatibility with cell target material. Viability analysis with FDA revealed a higher fraction of active cryptophyte cells in the upper reaches, the area of their dominance, and a lower fraction of active cells in the lower slough. It was concluded that cell death (as defined by a lack of FDA-linked esterase enzyme activity) is an important force structuring the phytoplankton community of Elkhorn Slough. 


\section{ACKNOWLEDGEMENTS}

This work was supported by the Sanctuary Integrated Monitoring Network (SIMoN) as a part of the effort to characterize the planktonic community of Elkhorn Slough, California. I would like to thank my Biological Oceanography labmates for support in the field and lab, as well as my MLML colleagues and friends for encouragement and fond memories. The assistance of the MLML administrative staff, and the ability of those at Small Boats to keep things running smoothly, were instrumental for the success of this project and completion of my thesis for which I am very grateful. I am very appreciative of the valuable support, feedback, and experiences

during my time at MLML provided by my committee members, Dr. Geller and Dr. Bartl. I am most indebted to my advisor, Dr. Nick Welschmeyer, who taught me how to do science for which I will always be grateful. His skill, knowledge, and consideration greatly enhanced the quality of this thesis. Finally. I would like to thank my Mom, Dad, and sister Stefanie for their enduring and unconditional support and encouragement. 


\section{TABLE OF CONTENTS}

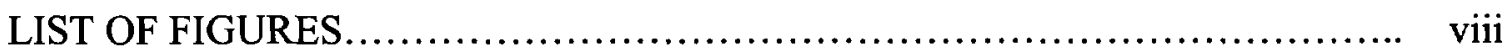

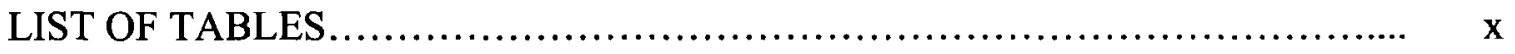

INTRODUCTION..................................................... 1

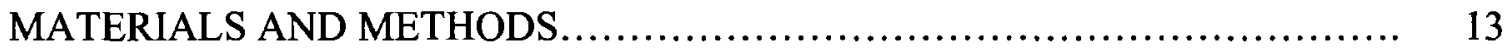

I. Sampling..................................................... 13

II. Flow cytometric analysis......................................... 14

III. Size fractionation analysis..................................... 18

a. Chlorophyll $a(\mathrm{Chl} a)$ analysis.................................. 18

b. Flow cytometric and microscopic analysis......................... 18

IV. Vital assays.................................................. 19

a. Cell digestion................................................ 19

b. SYTOX Green................................................... 19

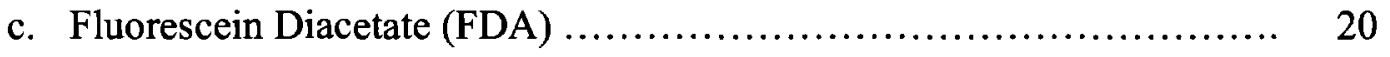

V. Vital stain protocols, performance and verification..................... 21

a. Killed phytoplankton experiments............................... 21

b. Natural cell death: Senescent culture experiments.................... 22

c. Environmental samples......................................... 22

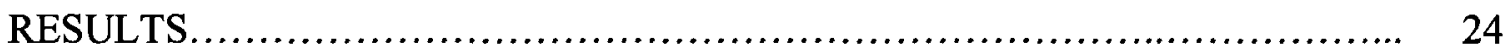

I. Characterization of physico-chemical conditions....................... 24

II. Phytoplankton community structure of upper Elkhorn Slough ............ 27

III. Size fractionation of upper Elkhorn Slough phytoplankton............... 29 
IV. Vital stain protocols, performance and verification.................... 34

a. Killed phytoplankton experiments............................... 34

i. ${ }^{14} \mathrm{C}$ incorporation experiments............................... 34

ii. Cell digestion vs. SYTOX Green: Ultraviolet light killed cells....... 35

b. Natural cell death: Senescent culture experiments................... 35

i. Cell digestion vs. SYTOX Green: Natural cell death................. 35

c. Vital assay performance on environmental samples.................. 38

V. Environmental viability patterns.................................. 44

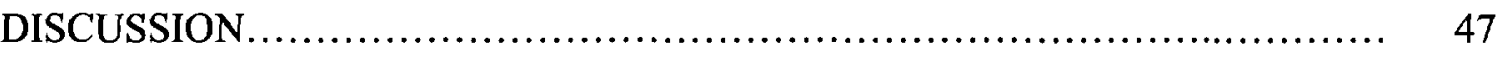

I. Phytoplankton community structure of upper Elkhorn Slough............ 47

II. Analysis of viability in natural samples: Assay selection and significance.. 50

III. Vitality of phytoplankton in Elkhorn Slough......................... 56

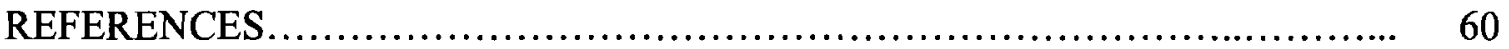




\section{LIST OF FIGURES}

Figure 1. Selected phytoplankton viability studies published from 1971 present.

Figure 2. Phytoplankton community structure pigment analysis in Elkhorn Slough.

Figure 3. Sanctuary Integrated Monitoring Network (SIMoN) sampling stations (1-10) in Elkhorn Slough.

Figure 4. Discrimination of picoeukaryotes and Synechococcus using phycobilin fluorescence.

Figure 5. Temperature $\left({ }^{\circ} \mathrm{C}\right)$ at each station for all sampling dates (21 February 2007 - 25 June 2007)

Figure 6. Salinity (PSU) at each station for all sampling dates (21 February 2007 - 25 June 2007).

Figure 7. Dissolved organic matter (DOM) at ten stations in Elkhorn Slough......

Figure 8. Average 1\% light level $( \pm \mathrm{SD})$ shown with bottom depth at ten stations in Elkhorn Slough.

Figure 9. Cytograms showing locations of A) large phytoplankton populations (A instrument settings; Table 5) and B) small phytoplankton populations ( $\mathrm{B}$ instrument settings).

Figure 10. Cell concentrations of A) small cryptophytes and B) picoeukaryotes at 10 stations in Elkhorn Slough throughout sampling period.

Figure 11. Cell density pattern of A) small cryptophytes and B) picoeukaryotes in Elkhorn Slough

Figure 12. Flow cytometric analysis of Elkhorn Slough phytoplankton populations after size fractionation.

Figure 13. Size fractionated biomass (Chlorophyll $a$ ) in upper Elkhorn Slough...

Figure 14. Epifluorescence micrographs of Elkhorn Slough A) large cryptophytes and B) small cryptophytes and picoeukaryotes. 
Figure 15. Verification of SYTOX Green fraction dead in Dunaliella sp. with cell-specific production rate.........................................

Figure 16. Complex SYTOX Green staining patterns in Dunaliella sp........... 36

Figure 17. Complex SYTOX Green staining patterns in Phaeodactylum sp....... 37

Figure 18. The effect of cell digestion and heat treatment on the optical properties of Chroomonas sp. phytoplankton cells........................... 38

Figure 19. SYTOX Green performance in an Elkhorn Slough natural sample..... 40

Figure 20. FDA response of small cryptophyte algae in Elkhorn Slough.......... 41

Figure 21. Optimal FDA stain time for small cryptophytes.................... 43

Figure 22. Fraction of Elkhorn Slough small cryptophytes in three FDA response categories (A-E) and corresponding cell concentrations (F-J) for ten stations in Elkhorn Slough on five sampling dates................. 45

Figure 23. Summary of viability data in Elkhorn Slough...................... 46 


\section{LIST OF TABLES}

Table 1. Vital stains used in studies of environmental microorganism viability.. 5

Table 2. Studies quantifying viability of natural phytoplankton communities.... 7

Table 3. Sampling coordinates....................................... 14

Table 4. Sampling dates............................................ 15

Table 5. Commonly used flow cytometer settings......................... 16

Table 6. Comparison of estimates of dead cells in senescent algal cultures obtained with the cell digestion assay and SYTOX Green............ 35 


\section{INTRODUCTION}

Planktonic, photosynthetic microorganisms fuel food webs, affect global climate through production of oxygen and consumption of carbon dioxide, and influence biogeochemical cycling of elements such as nitrogen, phosphorus, and silica. Because of this important role in both marine and freshwater systems, much research attention has been focused on studying rates of microalgal growth, production and mortality (Kirchman 1999, Bidle and Falkowski 2004, Franklin et al. 2006).

Until recently, the only major sources of phytoplankton loss were considered to be grazing and sinking and it was otherwise assumed that cells would divide indefinitely (Kirchman 1999). However, the paradoxical observation of "crashing" algal cultures and the inability of researchers to balance the algal growth equation with losses from grazing and downward flux alone have long suggested that there may be additional sources of phytoplankton mortality (Walsh 1983, Franklin et al. 2006).

Recent advances in understanding phytoplankton loss include the discovery of an auto-mortality pathway in phytoplankton and of high loss rates due to viral lysis (Agustí et al. 1998, Berges and Falkowski 1998). These studies confirm that grazing and downward flux are not the only significant loss terms for phytoplankton and highlights cell death as a force in controlling population dynamics of phytoplankton. A complete awareness of the forces structuring phytoplankton communities in the ocean must incorporate an assessment of in-situ physiology if we are to truly appreciate the role of phytoplankton in these systems. Unfortunately, there are relatively few studies that 
measure the magnitude of cell death or prevalence of dead cells in nature (Hayakawa et al. 2008). There is increased recognition that quantifying and understanding unicellular viability in nature is important to understand environmental processes, yet it is practically challenging for several reasons (Porter et al. 1997, Joux \& Lebaron 2000, Veal et al. 2000).

Microorganism viability is generally defined by both the ability to divide and be metabolically active (Nebe-von Caron and Badley 1995, Joux and Lebaron 2000). However, traditional methods designed to estimate the quantity of live cells in a given population rely solely on laboratory incubations of cells in growth medium, e.g., most probable number (MPN) technique (Rowe et al. 1977, Woomer et al. 1990). This growth approach is often inadequate since the cells that proliferate under typical laboratory conditions may not be representative of the community or its in-situ activity.

For example, in marine systems only $0.1-1 \%$ of total bacteria typically grow and form colonies on agar plates, a phenomenon which is described as the "great plate count anomaly" (Staley \& Konopka 1985). The most simple explanation as to why the remaining $99-99.9 \%$ of bacterial cells do not form colonies is that the cells are dead. However, more rigorous and careful culturing methods have allowed up to $60 \%$ of total marine bacterial cells to be cultivated suggesting that rather than dead, these cells don't grow under the conditions provided in the laboratory (Connon and Giovannoni 2002, Button et al. 1993). Since culture methods introduce a bias that skews the interpretation of the physiological activity of cells in nature, assays of other vital characteristics that can be quantified in-situ are more desirable. 
Metabolic activity or "vigor" of natural phytoplankton communities is most often measured through indicators of photosynthetic activity such as oxygen evolution or ${ }^{14} \mathrm{C}$ incorporation (Peterson 1980). These measurements are bulk rates and have formed the basis of much of what we know about ocean function, yet they lack specificity to any functional group within the autotrophic fraction of the plankton. More specificity can be obtained by measuring the rate of ${ }^{14} \mathrm{C}$ incorporation into taxonomically significant pigments (Goericke and Welschmeyer 1993). While these measurements are specific and can yield valuable information about how communities and ecosystems are structured, obtaining the measurements can be complicated and requires a high level of expertise. Furthermore these pigment-specific rates contain no information on heterogeneity within a given population since the rate is integrated for the whole community containing a given pigment.

Achieving taxonomic specificity for physiological measurements such as growth rate, production, activity and death remains a challenge in environmental microbiology. Single cell analyses, through the use of the microscope or with flow cytometry provide a direct way to make inferences about physiology at the cellular level (Collier 2000). Though many potential single-cell in-situ physiological assays exist such as autoradiography, estimates of RNA: DNA ratios, resistance to enzymatic digestion, and vital dyes, none is entirely straightforward, universal nor well accepted (Veal et al. 2000). Currently, the most frequently used method and arguably most direct method is the use of vital stains. 
Vital stains are dyes that discriminate live and dead cells in a given population based on a variety of proxies of viability such as membrane integrity or metabolic activity (esterase enzyme activity; respiration). Vital stains have been primarily developed for use in human health-related research on cell cultures maintained in stable laboratory conditions where tests verifying the performance and validity of the live/dead score are easily conducted. Unfortunately, environmental variability in natural types of microorganisms in addition to complex physical and chemical environments renders many vital dyes unsuitable (Agustí \& Sánchez 2002). In addition, many vital stains are not suitable for use with phytoplankton due to interference with chlorophyll autofluorescence (Table 1).

No comprehensive studies have been conducted that systematically test the performance of the variety of vital stains on phytoplankton viability, yet these assays are beginning to be used routinely in toxicological and other applied studies (Gilbert et al. 1992, Franklin et al. 2001, Regel et al. 2002). The most commonly employed vital stains for viability detection in phytoplankton are fluorescein diacetate (FDA) and SYTOX Green (Figure 1). FDA is a non-fluorescent enzyme substrate that diffuses across the cellular membranes of both live and dead cells. In the cytoplasm of active cells, nonspecific esterase enzymes cleave the FDA molecule into a green fluorescent product, allowing for the discrimination of esterase active and inactive cells. Inactive cells, those without enzymatic activity, remain non-fluorescent. SYTOX Green is a fluorescent polar molecule that is impermeant to live cells. It penetrates the compromised cell membrane 


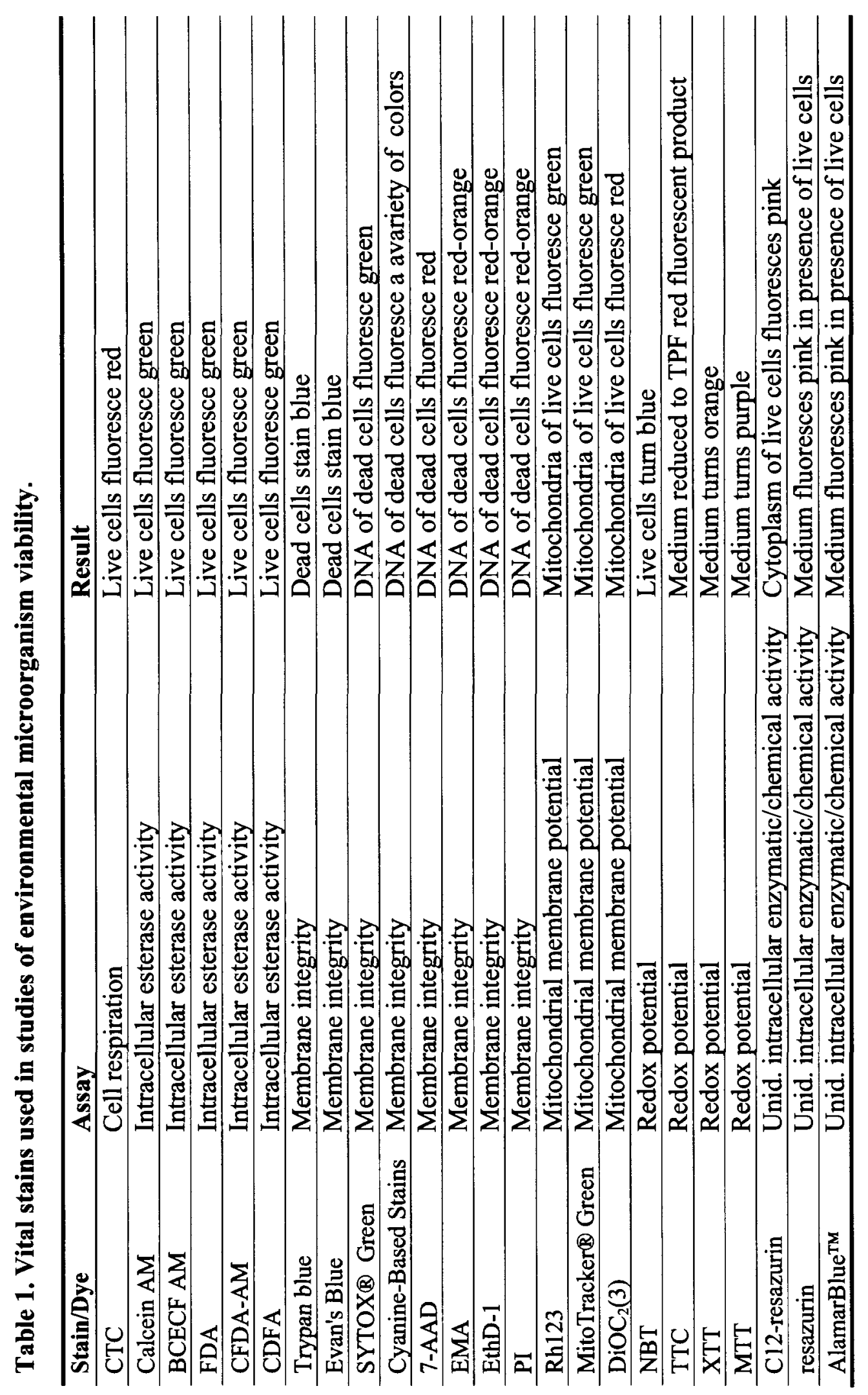




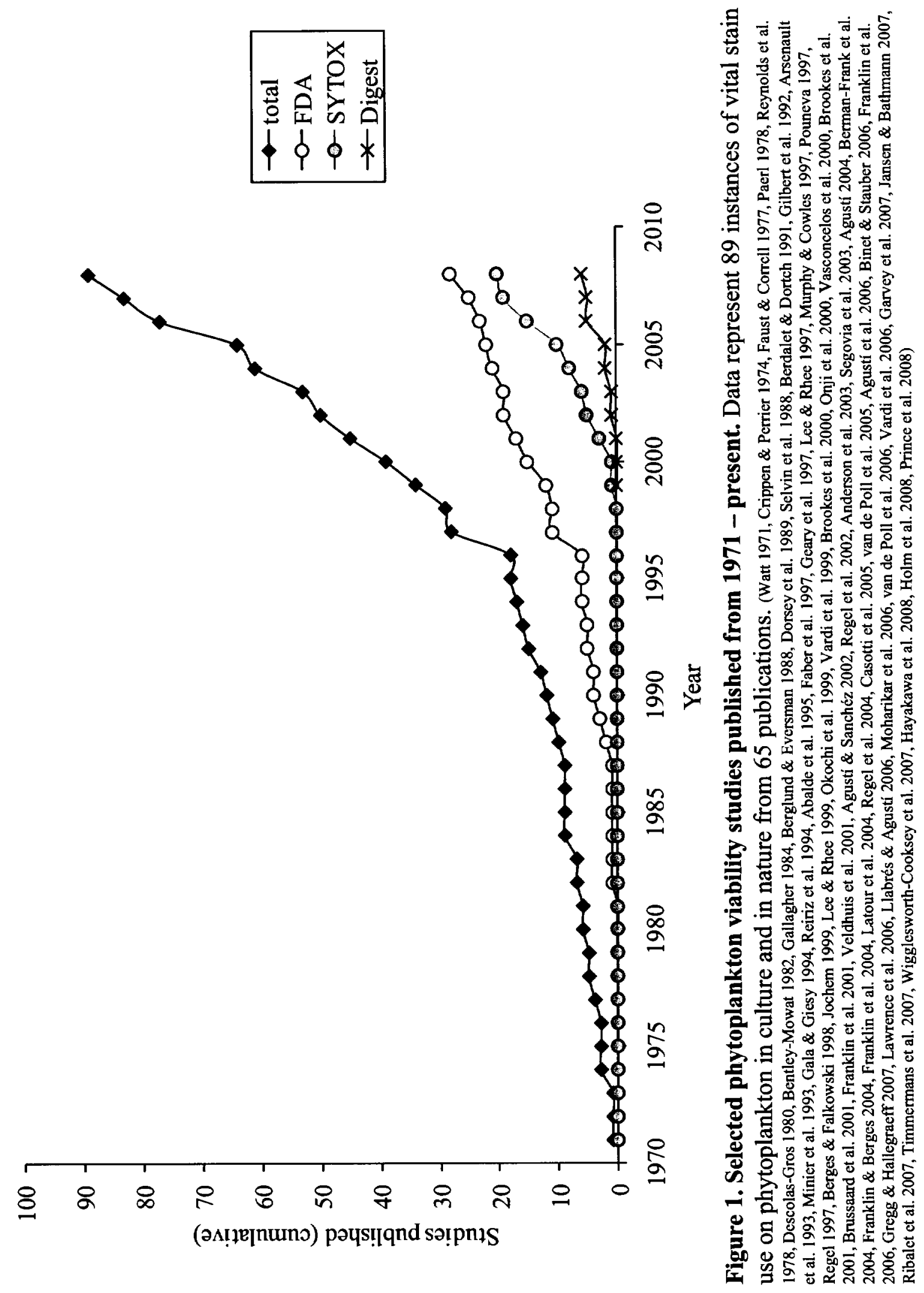


of dead cells and binds to double-stranded DNA, causing the nucleus of dead cells to fluoresce green (Roth 1997, Veldhuis 2001).

Out of 61 studies published since 1988 measuring phytoplankton viability, only seven measure viability of environmental populations where variables such as particle load, cell diversity, culture age and stain conditions ( $\mathrm{pH}$, temperature, salinity) cannot be easily controlled (Table 2). These factors are known to alter the performance of some vital stains and as a result only one of these field studies used a stain method (SYTOX Green, Veldhuis et al. 2001). The remaining six studies used the cell digestion assay, a non-stain method that involves the exposure of cells to a cocktail of enzymes that digests and removes dead cells with compromised outer membranes (Darzynkiewicz et al. 1994, Agustí and Sánchez 2002). One of the principal advantages of the cell digestion assay is the ease of data interpretation due to limited background staining, rendering it more useful in environments with high particle loads.

Table 2. Studies quantifying viability of natural phytoplankton communities.

\begin{tabular}{|c|c|}
\hline Source & Title \\
\hline Veldhuis et al. 2001 & $\begin{array}{l}\text { Cell death in phytoplankton: correlation between changes in } \\
\text { membrane permeability, photosynthetic activity, pigmentation } \\
\text { and growth }\end{array}$ \\
\hline $\begin{array}{l}\text { Agustí \& Sánchez } \\
2002\end{array}$ & $\begin{array}{l}\text { Cell viability in natural phytoplankton communities quantified } \\
\text { by a membrane permeability probe }\end{array}$ \\
\hline Agustí 2004 & $\begin{array}{l}\text { Viability and niche segregation of Prochlorococcus and } \\
\text { Synechococcus cells across the Central Atlantic Ocean }\end{array}$ \\
\hline Agustí et al. 2006 & Cell death in lake phytoplankton communities \\
\hline $\begin{array}{l}\text { Llabrés and Agustí } \\
2006\end{array}$ & $\begin{array}{l}\text { Picoplankton cell death induced by UV radiation: Evidence for } \\
\text { oceanic Atlantic communities }\end{array}$ \\
\hline $\begin{array}{l}\text { Alonso-Laita and } \\
\text { Agustí } 2007\end{array}$ & $\begin{array}{l}\text { Contrasting patterns of phytoplankton viability in the } \\
\text { subtropical NE Atlantic Ocean }\end{array}$ \\
\hline $\begin{array}{l}\text { Hayakawa et al. } \\
2008\end{array}$ & $\begin{array}{l}\text { Differences in cell viabilities of phytoplankton between spring } \\
\text { and late summer in the northwest Pacific Ocean }\end{array}$ \\
\hline
\end{tabular}


Flow cytometers are ideal instruments to detect vital staining since they are used to quantitatively analyze light scatter and fluorescence properties of individual cells in suspension (Collier 2000, Veal et al. 2000). Flow cytometers hydrodynamically focus a sample stream with sheath fluid allowing data to be obtained for a single cell. When the data are plotted, generally biparametrically, similar cell types cluster together distinctly allowing for discrimination of optically discrete populations. In environmental samples it cannot be assumed that optically discrete populations are composed of a single taxon since it is possible that several taxa may be of the same type and will cluster together. This occurrence must be taken under consideration during experimental design and data interpretation especially when analyzing field data. These instruments are optimized to count particles at a maximum rate of 800 events $\mathrm{s}^{-1}$ or in the range of $10^{5}-10^{7}$ cells ml $^{-1}$ and the minimum cell concentration required is approximately 500 cells ml$^{-1}$ (Collier 2000, Marie et al. 2005). In complex environmental samples where particulates and sample diversity can be high, higher minimum cell densities $\left(\sim 2 \times 10^{4}\right.$ cells $\left.\mathrm{ml}^{-1}\right)$ may be necessary to visually discriminate a population cluster from background noise.

Flow cytometry allows for accurate determination of cell concentration of a wide variety of cell types and has been frequently used in oceanography since the $1980 \mathrm{~s}$ (Legendre et al. 2001). The most important discovery involving the use of flow cytometry in oceanography to date is the detection of the globally abundant and significant cyanobacterium Prochlorococcus (Chisholm et al. 1988). Characterizing the distribution and abundance of microorganisms has been the main focus of oceanographic studies utilizing flow cytometry thus far. Unfortunately these data ignore the functional 
role of these cells and assume that presence indicates some degree of health and growth. It is currently unknown whether dead cells comprise a large fraction of the observed abundance profiles in many environmental populations, yet there is evidence that a large fraction (up to 88\%) of cells in nature may be dead (Veldhuis et al. 2001, Agustí 2004, Hayakawa et al. 2008).

To understand the role of cell death in phytoplankton dynamics, viability must be quantified over a temporal or spatial gradient in which the phytoplankton community is variably structured. Unfortunately there are very few environments in which phytoplankton communities are structured so predictably as to allow investigation of the relationship between abundance and viability. Elkhorn Slough (central California) is characterized by a predictable and persistent phytoplankton community structure gradient that was discovered and characterized during a 5-year monitoring study funded by the Sanctuary Integrated Monitoring Network (SIMoN). The upper reaches of Elkhorn Slough were revealed to be nearly completely dominated by cryptophyte algae as evidenced by high ratios of their signature carotenoid pigment alloxanthin to total chlorophyll $a$ (Chl $a$; Figure 2; Welschmeyer and Younan unpubl. ). The relative contribution of alloxanthin to the total photosynthetic biomass ( $\mathrm{Chl} a$ ) decreases towards the slough mouth. The opposite pattern was documented for the diatom carotenoid fucoxanthin, indicating a shift in community structure from diatom-dominated coastal lower reaches towards a cryptophyte dominated inland regions.

Cryptophytes are eukaryotes that range in size from 3 to $>50 \mu \mathrm{m}$ and are found in freshwater, brackish and marine environments (Klaveness 1989). They are thought to be 

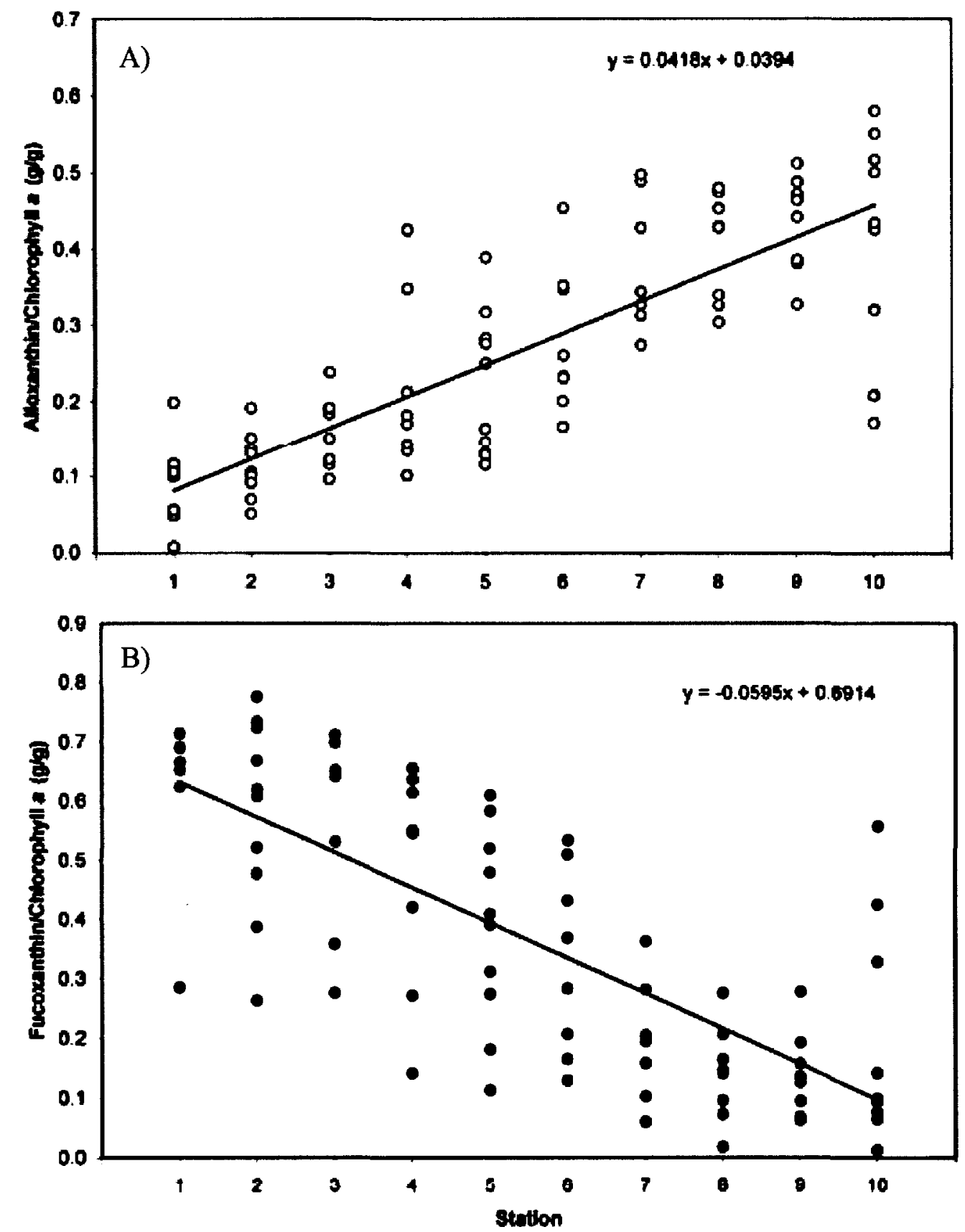

Figure 2. Phytoplankton community structure pigment analysis in Elkhorn Slough. Ratio of A) Alloxanthin: $\mathrm{Chl} a$ representing the relative abundance of cryptophyte algae and B) Fucoxanthin: Chl $a$ representing the relative abundance of diatoms. Data represent ten cruises from Elkhorn Slough (data from Welschmeyer and Younan unpubl.). 
most dominant and successful in areas of attenuated light and high dissolved organic matter (DOM) since they are physiologically adapted to these conditions (Bergmann 2004). Cryptomonads are exceedingly complex in their evolutionary history and are considered to be chimaeras of a red alga and an unidentified host eukaryote (Cerino \& Zingone 2007). Most of the research attention paid to cryptophyte algae has focused on understanding their evolutionary significance and the process of the secondary endosymbioses that have resulted in the strains present today. Cryptophytes or "hidden" algae are difficult to preserve, are often not abundant and are difficult to identify due to a variety of morphological characteristics (Gieskes and Kraay 1983, Cerino and Zingone 2007). Consequently there is a dearth of research on the role of cryptophytes in microbial ecology and a lack of understanding about the forces structuring their abundance (Bergmann 2004).

In Elkhorn Slough, the pattern in cryptophyte abundance and distribution was found to be seasonally persistent yet discrepant with regard to variability in nitrate, temperature and salinity (Welschmeyer and Younan unpubl.). The upper Elkhorn Slough is characterized by low light levels and high levels of DOM which are the environmental conditions under which cryptophytes are expected to thrive (Bergmann 2004). It was hypothesized that these environmental conditions present in upper Elkhorn Slough promote optimal growth of cryptophyte algae thereby allowing them to outcompete other phytoplankton. Further, it was expected that healthy and vital cryptophytes would be found in the upper reaches of Elkhorn Slough and that the transition away from these conditions would be marked by an increase in cell death (decreased viability) thus 
allowing successful competition from other autotrophs. The principal objective of this thesis is to quantify population-level viability across a gradient in cryptophyte abundance to determine if the upper Elkhorn Slough phytoplankton community is structured by factors influencing cell death.

In order to quantify viability of a specific taxonomic fraction, population-specific measures such as the use of vital stains are imperative. Single cell specific vital assays (vital stains, cell digestion) are the most direct methods available to discriminate live and dead cells. Flow cytometry was chosen for use in Elkhorn Slough since the high particle load and sensitivity of the vital assays and cryptophyte cells to fixation and filtration render microscopy inappropriate. First, the target populations whose patterns in cell density are concomitant with the observed pigment pattern were located flow cytometrically. Second, a suitable viability assay protocol was established for the natural target populations. Lastly, patterns in viability of the identified target population were quantified to determine the extent of cell death as a structuring force in the Elkhorn Slough. 


\section{MATERIALS AND METHODS}

\section{Sampling}

Surface water samples were collected in darkened $1.0 \mathrm{~L}$ polycarbonate bottles (rinsed three times at each station before filling) at ten sites in the main channel of the Elkhorn Slough (Figure 3); stations were distanced approximately $1 \mathrm{~km}$ from one another (Table 3).

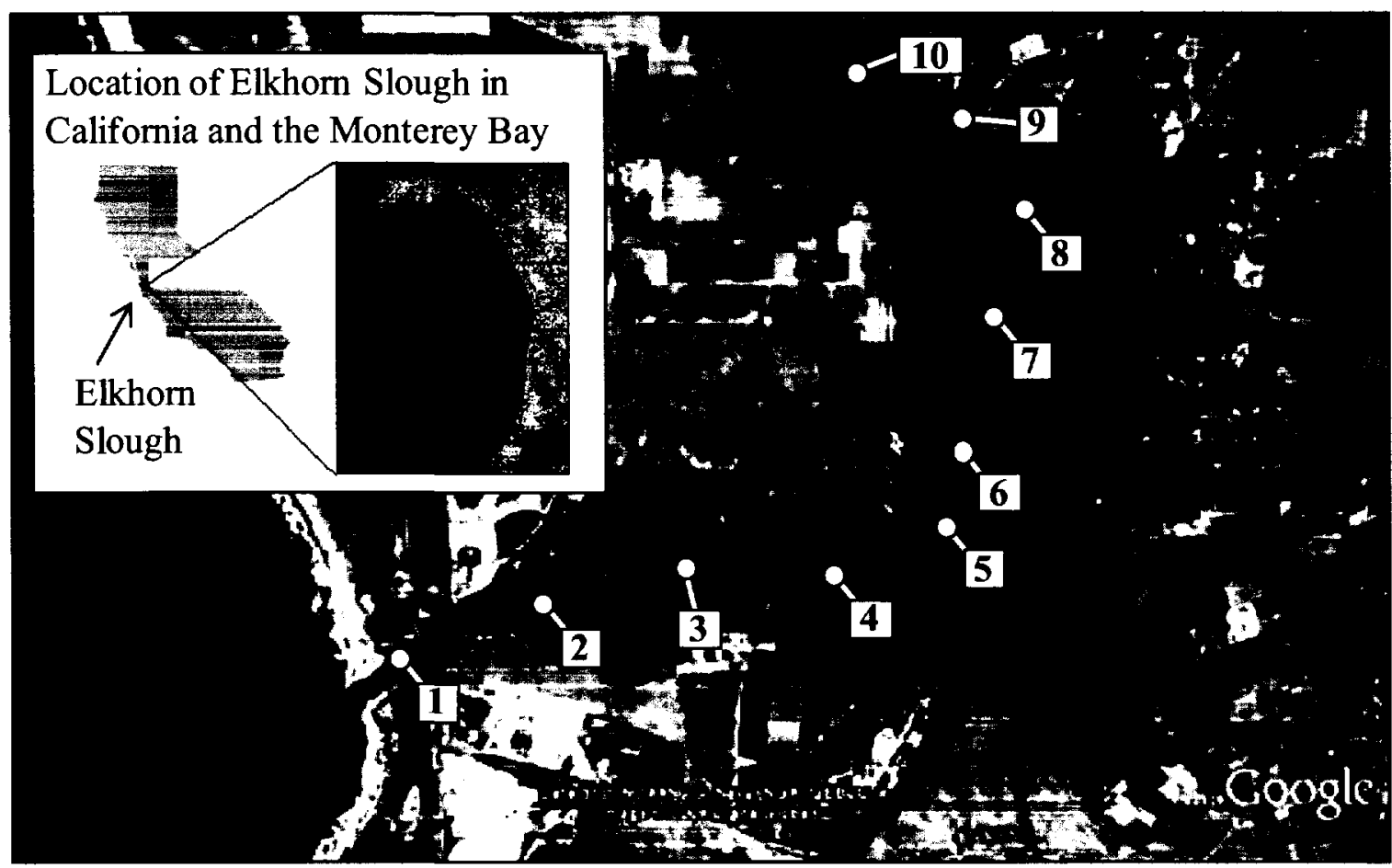

Figure 3. Sanctuary Integrated Monitoring Network (SIMoN) sampling stations (110) in Elkhorn Slough. Sampling stations were established by the Monterey Bay National Marine Sanctuary funded SIMoN program (2002-2007).

Temperature, salinity, and photosynthetically active radiation (PAR) were measured at each station using a SBE 19 SEACAT Profiler CTD (Sea-Bird Electronics, Inc.) equipped with a $4 \pi$-quantum sensor (LI193, Li-Cor). Flow cytometric analysis of phytoplankton community composition and viability was conducted on fresh samples. 
Table 3. Sampling coordinates.

\begin{tabular}{|c|c|}
\hline Station & Coordinates: WGS84 \\
\hline 1 & $\begin{array}{l}\text { N } 36^{\circ} 48.558^{\prime} \\
\text { W } 121^{\circ} 47.155^{\prime}\end{array}$ \\
\hline 2 & $\begin{array}{l}\text { N } 36^{\circ} 48.749^{\prime} \\
\text { W } 121^{\circ} 46.462^{\prime}\end{array}$ \\
\hline 3 & $\begin{array}{l}\text { N } 36^{\circ} 48.872^{\prime} \\
\text { W } 121^{\circ} 45.951^{\prime}\end{array}$ \\
\hline 4 & $\begin{array}{l}\text { N 36 } 36^{\circ} 48.809^{\prime} \\
\text { W } 121^{\circ} 45.449^{\prime}\end{array}$ \\
\hline 5 & $\begin{array}{l}\text { N } 36^{\circ} 48.975^{\prime} \\
\text { W } 121^{\circ} 44.892^{\prime}\end{array}$ \\
\hline 6 & $\begin{array}{l}\text { N } 36^{\circ} 49.337^{\prime} \\
\text { W } 121^{\circ} 44.744^{\prime} \\
\end{array}$ \\
\hline 7 & $\begin{array}{l}\text { N } 36^{\circ} 49.753^{\prime} \\
\text { W } 121^{\circ} 44.587^{\prime}\end{array}$ \\
\hline 8 & $\begin{array}{l}\text { N } 36^{\circ} 50.178^{\prime} \\
\text { W } 121^{\circ} 44.505^{\prime}\end{array}$ \\
\hline 9 & $\begin{array}{l}\text { N 36 } 50.430^{\prime} \\
\text { W } 121^{\circ} 44.894^{\prime}\end{array}$ \\
\hline 10 & $\begin{array}{l}\text { N } 36^{\circ} 50.641^{\prime} \\
\text { W } 121^{\circ} 45.234^{\prime}\end{array}$ \\
\hline
\end{tabular}

Samples were stored until analysis at $13^{\circ} \mathrm{C}$. Algal pigment samples and nutrient samples were prepared and archived, though not analyzed for this study. Within 24 hours, water samples were filtered onto Whatman GF/F filters and stored in liquid $\mathrm{N}_{2}$ for pigment analysis. Filtrate from $\mathrm{GF} / \mathrm{F}$ filters was stored at $-20^{\circ} \mathrm{C}$ for nutrient analysis. Aliquots from the nutrient samples were removed for DOM analysis using fluorometric technique; specifically, using marine shallow transitional

excitation/emission DOM maxima $(310 / 423 \mathrm{~nm})$ as described by Coble (1996).

Additional samples were collected occasionally from the dock at Kirby Park (N $36^{\circ}$ $\left.50.430^{\prime} \mathrm{W} 121^{\circ} 44.894^{\prime}\right)$ for size fractionated chlorophyll $a(\mathrm{Chl} a)$, flow cytometric and microscopic analysis. See Table 4 for sampling dates and analyses conducted.

\section{Flow cytometric analysis}

A Becton-Dickinson FACSort flow cytometer equipped with a $488 \mathrm{~nm}$ argon-ion laser was used for all flow cytometric analysis. Barnstead NANOpure water was used as sheath fluid. All seawater samples were prefiltered with $73 \mu \mathrm{m}$ Nitex mesh to prevent clogging of the sample intake. Data were acquired with CellQuest software. Typical 


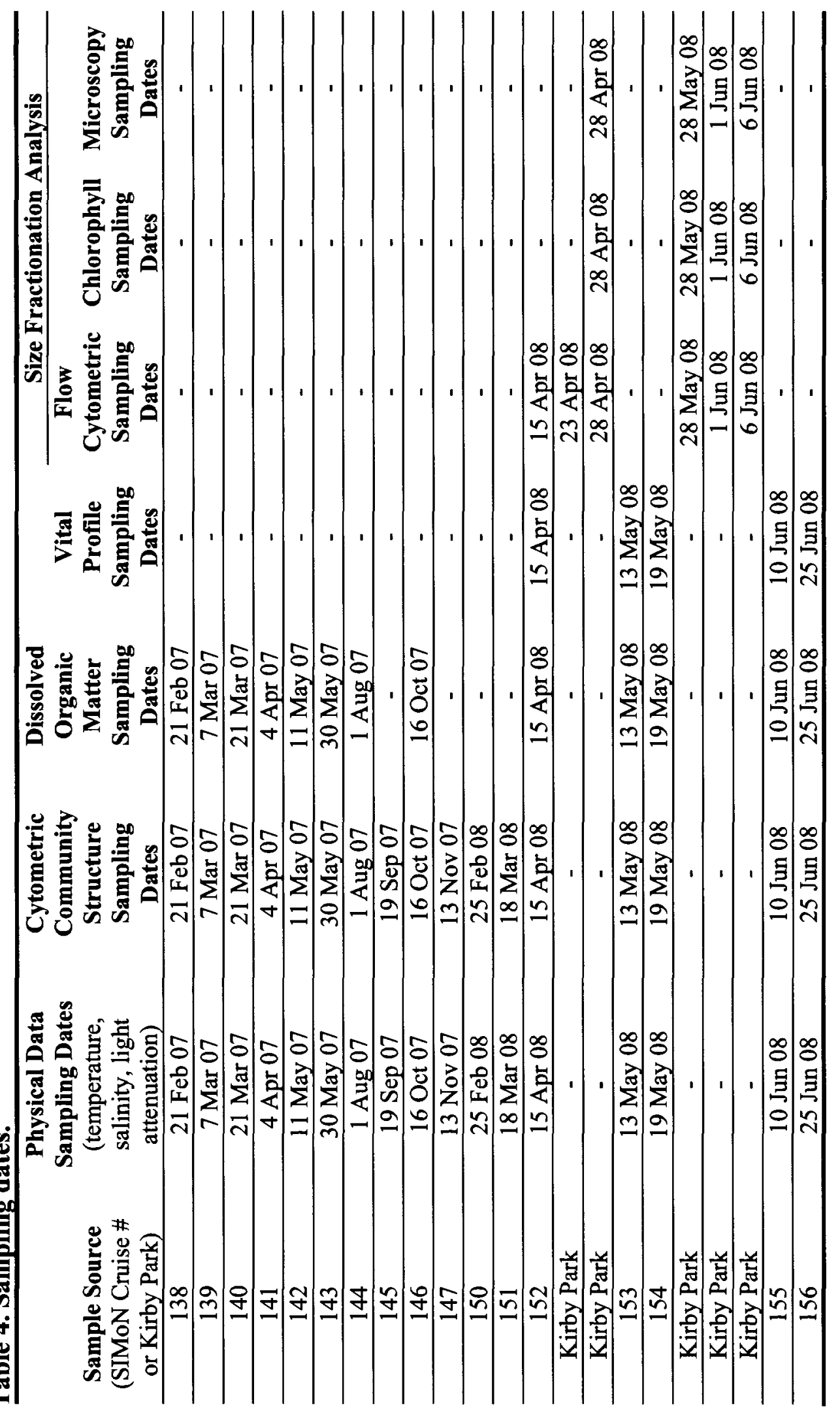


settings for larger phytoplankton cells were FSC: E-01, SSC: 200, FL1: 500, FL2: 400, FL3: 300 and were all collected in logarithmic mode with threshold set on FL3 at 52 (identified as A settings; Table 5). Smaller cells were enumerated and characterized at FSC: E00, SSC: 300, FL1: 500, FL2: 750, FL3: 450 and were also collected in logarithmic mode with threshold set on FL3 at 52 (B settings). Settings were adjusted slightly if necessary.

Table 5. Commonly used flow cytometer settings. The A settings were used for large phytoplankton cells and B settings for smaller cells. All channels set in log mode.

\begin{tabular}{llcccc}
\hline & & \multicolumn{2}{c}{ A Settings } & \multicolumn{2}{c}{ B Settings } \\
\cline { 2 - 6 } & Detector & Voltage & Threshold & Voltage & Threshold \\
\hline FSC & Forward $\left(180^{\circ}\right)$ light scatter & E-1 & - & EOO & - \\
\hline SSC & Side $\left(90^{\circ}\right)$ light scatter & 200 & - & 300 & - \\
\hline FL1 & $\begin{array}{l}\text { Green Fluorescence } \\
530 / 30 \mathrm{~nm}\end{array}$ & 500 & - & 500 & - \\
\hline FL2 & $\begin{array}{l}\text { Orange Fluorescence } \\
575 / 26 \mathrm{~nm}\end{array}$ & 400 & - & 750 & - \\
\hline FL3 & $\begin{array}{l}\text { Red Fluorescence } \\
\text { Long Pass 650 nm }\end{array}$ & 300 & 52 & 450 & 52 \\
\hline
\end{tabular}

To ensure the coincidence threshold was not crossed the event rate was kept under 800 cells s $^{-1}$ (Marie et al. 2005). Flow rate was adjusted depending on the particle concentration and both the low flow setting (approx. $12 \mu 1 \mathrm{~min}^{-1}$ ) and the high flow setting (approx. $60 \mu 1 \mathrm{~min}^{-1}$ ) were used as deemed appropriate. Flow rate was calibrated by the liquid-volume procedure outlined in (Marie et al. 2005) to eliminate the need for calibration with fluorescent microspheres. Data analysis was conducted with CellQuest, CYTOWIN (version 4.31) and FCS Express V3 software. 
Elkhorn slough phytoplankton populations were gated and counted on the basis of chlorophyll autofluorescence (FL3) and orange phycobilin autofluorescence (FL2). Large cells could easily be discriminated from other particles on the basis of forward scatter, side scatter, chlorophyll fluorescence and orange fluorescence. In the two populations of small cells present in Elkhorn Slough, identified as small cryptophytes and picoeukaryotes, only the small cryptophytes were easily discriminated using forward scatter and side scatter, and chlorophyll and orange fluorescence signals. Picoeukaryotes and Synechococcus could only be discriminated on the bases of orange fluorescence (FL2) having otherwise identical chlorophyll fluorescence and forward scatter and side scatter signals (Figure 4).

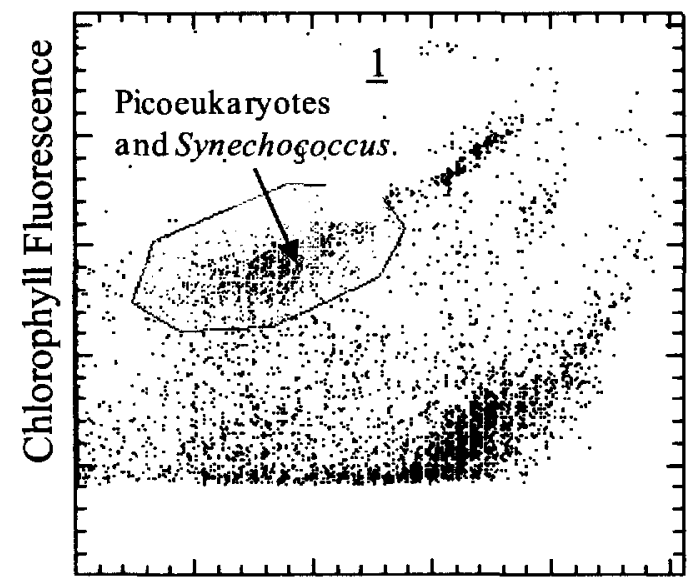

Forward Scatter

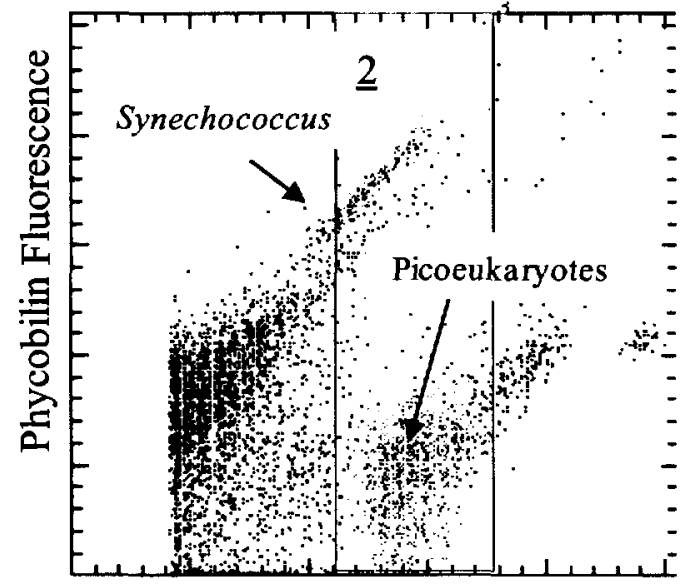

Chlorophyll Fluorescence

Figure 4. Discrimination of picoeukaryotes and Synechococcus using phycobilin fluorescence. Data represent a single file plotted in to depict 1) a single population and 2) separate populations discriminated on the basis of phycobilin fluorescence. Axes are arbitrary fluorescence or light scatter units depicted on a log scale. Chlorophyll fluorescence determined from the red emission detector (FL3); phycobilin fluorescence determined from the orange emission detector (FL2). 


\section{Size fractionation analyses}

a. Chlorophyll $a(\mathrm{Chl} a)$ analysis

Seawater was filtered onto Whatman GF/F filters (nominal pore size $0.7-\mu \mathrm{m}$ ) and polycarbonate filters with $10-\mu \mathrm{m}, 5-\mu \mathrm{m}$, and $3-\mu \mathrm{m}$ pore sizes. Filtration was nonsequential meaning that the filtrate from each filter was discarded rather than analyzed and raw water was filtered onto each size filter. Pigments were extracted in $1.2 \mathrm{ml}$ of $90 \%$ acetone and stored at $-20^{\circ} \mathrm{C}$ for a minimum of 24 hours. The extract was analyzed with a TD-700 fluorometer (Turner Designs). Chl $a$ content of each size fraction was calculated by subtracting the measured $\mathrm{Chl} a$ concentrations $[\mathrm{chl} a]$ in the larger fractions. Equations are shown below.

$$
\begin{aligned}
& {[\operatorname{chl} a]_{10 \mu \mathrm{m}}=[\operatorname{chl} \mid a]_{10 \mu \mathrm{m}}}
\end{aligned}
$$

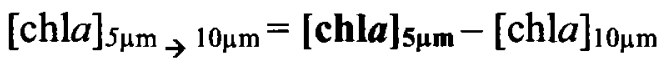

$$
\begin{aligned}
& {[\mathrm{chla}]_{3 \mu \mathrm{m}} \rightarrow 5 \mu \mathrm{m}=[\operatorname{chla}]_{3 \mu \mathrm{m}}-[\operatorname{chl} a]_{5 \mu \mathrm{m}}-[\operatorname{chl} a]_{10 \mu \mathrm{m}}}
\end{aligned}
$$

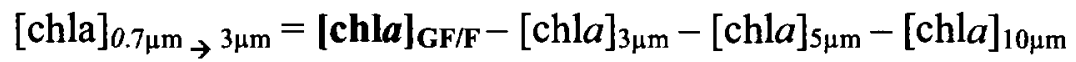

b. Flow cytometric and microscopic analysis

Seawater was filtered through the following filter sizes $(73-\mu \mathrm{m}, 10-\mu \mathrm{m}, 5-\mu \mathrm{m}, 3-$ $\mu \mathrm{m}$ and $1-\mu \mathrm{m})$. The filtrate was then characterized and enumerated flow cytometrically to determine what size filter excluded each population present in the sample. The same filtrate was then fixed with glutaraldehyde $(2 \%)$ and filtered onto $0.4-\mu \mathrm{m}$ polycarbonate 
filters for epifluorescent microscopic visualization and identification of phytoplankton in each size class.

\section{Vital assays}

a. Cell digestion

Stock solutions of DNAse I ( $800 \mu \mathrm{g} \mathrm{ml}^{-1}$ in HBSS without phenol red) and trypsin (2\% in HBSS without phenol red) were made following Agusti and Sánchez (2002) and kept frozen at $-20^{\circ} \mathrm{C}$ until use. The cell digestion method was applied by adding $200 \mu \mathrm{l}$ of DNAse I to $1 \mathrm{ml}$ of sample and incubating for $15 \mathrm{~min}$ at $37^{\circ} \mathrm{C}$. Then $200 \mu \mathrm{l}$ of the trypsin solution was added to the sample tube and incubated for another $30 \mathrm{~min}$. The enzymatic digestion was stopped by placing samples on ice. Enzymes were obtained from Sigma-Aldrich (DNAse I: DN25-100mg, trypsin T9201-500mg, HBSS H-1347). Fractions viable were determined from counts of digested samples divided by counts of undigested replicate samples.

\section{b. SYTOX Green}

SYTOX Green commercial stock is available in $5 \mathrm{mM}$ concentration in DMSO (S7020, Invitrogen). A working stock ( $50 \mu \mathrm{M}$ in DMSO) was made and stored at $-20^{\circ} \mathrm{C}$. SYTOX Green was added to a final concentration of $0.5 \mu \mathrm{M}(10 \mu 1$ working stock to 990 $\mu 1$ sample) and incubated in the dark at room temperature for approximately $15 \mathrm{~min}$ (Timmermans et al. 2007, Veldhuis et al. 2001). SYTOX Green is proprietary and the cost at the time of writing is published as $\$ 174$ for $250 \mu$ l. At the final concentration of 
$0.5 \mu \mathrm{M}$ and $1 \mathrm{ml}$ samples, this translates to a cost of $\$ 0.07 \mathrm{sample}^{-1}$. Populations were gated on the basis of forward scatter and chlorophyll fluorescence and staining was quantified in the green fluorescence channel.

\section{c. Fluorescein Diacetate (FDA)}

FDA can be obtained in small gram quantities from a variety of sources $(\mathrm{MW}=$ 416.39). A concentrated working stock was made ( $50 \mathrm{mM}$ ) by adding $0.1041 \mathrm{~g}$ to $5 \mathrm{ml}$ of DMSO. Then, $20 \mu \mathrm{l}$ of this working stock was added to $980 \mu \mathrm{l}$ of DMSO to make a 1 $\mathrm{mM}$ final working stock. This final working stock was added to a sample for a final concentration of $10 \mu \mathrm{M}$. Samples were incubated at room temperature and light conditions, though bright light was avoided. Various incubation times were tested and optimal incubation time for natural samples was determined to be a 3-7 min. The effect of working stock age was tested on staining ability and it was determined that there were no differences between the staining ability of fresh $1 \mathrm{mM}$ final working stocks and 6 month-old stocks (data not shown). The cost of FDA at the time of writing ranged from $\$ 18.08 \mathrm{~g}^{-1}$ (Fisher Scientific) to $\$ 64 \mathrm{~g}^{-1}$ (Invitrogen). At the final concentrations used of $10 \mu \mathrm{M}$ with $1 \mathrm{ml}$ samples, the cost is $\$ 0.02$ to $\$ 0.06$ per 100 samples.

Only small cells were measured for vital stain uptake due to limited densities of large cells during viability analysis. For stain uptake analysis, small cells were gated on the basis of forward scatter (FSC) and chlorophyll autofluorescence (FL3) as the spectral overlap from the increase in green fluorescence (FL1) impaired the gating of the target population on the preferred plot (FL3 vs. FL2; Figure 4). This precluded the stain uptake 
analysis of picoeukaryotes, as FL2 was the only parameter allowing for the distinction of picoeukaryotes and Synechococcus.

\section{Vital stain protocols, performance and verification}

There are relatively few instances where vital assays have been used with phytoplankton and even fewer instances in which the result they yield (fraction live and dead) has been verified with measures of either growth or metabolism. Therefore a series of experiments were devised to test and optimize assay protocols.

\section{a. Killed phytoplankton experiments}

Cultures of Dunaliella sp. (obtained from J. Smith, Moss Landing Marine

Laboratories) were killed by exposure to ultraviolet light $\left(16 \mathrm{~J} \mathrm{~m}^{-2}\right.$ or $5,000 \mu \mathrm{J}$ oulesx 100 for a $20 \mathrm{~cm}$ diameter dish) from a Stratagene Stratalinker UV Crosslinker 2400. The UVkilled cells were used to serially dilute fresh culture to yield variable fractions of live and dead cells. In two experiments, the fractions live and dead were assessed with SYTOX Green and then simultaneously assessed for photosynthetic activity as measured by ${ }^{14} \mathrm{C}$ incorporation (Peterson 1980). In a third experiment, fractions live and dead were assessed only with SYTOX Green and the cell digestion assay in order to compare the results obtained with each. 
b. Natural cell death: Senescent culture experiments

Three cultures of Dunaliella sp., Phaeodacytulum sp. (obtained from J. Smith, MLML) and Cryptomonas sp. (UTEX; LB2423) were sampled in batch culture stationary growth phase and analyzed with the cell digestion assay and SYTOX Green to compare the results obtained with both assays under a "realistic" scenario of cell death.

Presumably all three cultures had high fraction dead cells due to nutrient starvation. The cell digestion assay requires a $45 \mathrm{~min}$ incubation at $37^{\circ} \mathrm{C}$ and a subsequent termination on ice. Agusti and Sánchez (2002) note that this element of the assay alone may be stressful on cells as the heat and ice element of the protocol may lyse cells independent of digestion artificially increasing the numbers of dead cells. Therefore samples analyzed for cell digestion included an undigested control, a heat treated control and a digested sample.

Batch culture experiments were also conducted. The cryptomonad, Chroomonas sp. (CCMP269), was seeded into K medium and grown on a 12:12h L:D cycle under continuous stirring. It was monitored flow cytometrically every 2-4 days over the growth cycle for cell concentration and viability as determined with SYTOX Green and FDA.

\section{c. Environmental samples}

SYTOX Green, FDA and cell digestion were all applied to environmental samples to assess potential unforeseen complications such as non-specific background staining or signal interference. Use of the cell digestion assay was evaluated on environmental samples to determine if there were adverse effects of the $37^{\circ} \mathrm{C}$ incubation on cell 
concentration independent of digestion. SYTOX Green and FDA were also applied to Tetraselmis sp. culture (Reed Mariculture) that had been inoculated with test dust (Powder Technology Inc. course and medium test dust) which is routinely used to mimic ballast water and obscure detection of organic particles and was used here to determine the level of non-specific background staining with SYTOX Green. 


\section{RESULTS}

\section{Characterization of physico-chemical conditions}

Temperature, salinity, dissolved organic matter (DOM) levels and light intensity measured during the sampling period from 21 February 2007 - 25 June 2008 are summarized in Figures 5, 6,7 and 8. For sampling dates refer to Table 4. Temperature varied from a low of $9.8^{\circ} \mathrm{C}$ (Station 1,10 June 2008) to a high of $21.8^{\circ} \mathrm{C}$ (Station 10,19 May 2008). The average temperature was $12.87( \pm$ SD 1.91) and $16.85( \pm$ SD 2.67) at stations 1 and 10 respectively $(n=16)$. Horizontal temperature stratification was seasonally variable and was stronger in the non-winter (March - October) months (Figure 5). Salinity varied from 26.6 PSU (Station 10, 25 February 2008) to 37.1 PSU (Station $10,10$ June 2008$)$. The average salinity was $33.97( \pm$ SD 0.53$)$ and $33.47( \pm$ SD 2.90$)$ at stations 1 and 10 respectively $(n=16)$. Horizontal stratification (from stations $1-10)$ was generally moderate (average maximum observed difference minus minimum observed difference $=2.0$ ) except following rainfall in which the upper slough became hyposaline relative to the lower slough (Figure 6). In the summer months, the upper slough became hypersaline.

DOM was on average 6.98 times higher $( \pm$ SD $2.11, \mathrm{n}=14)$ in the upper slough than the lower slough (calculated as the maximum observed value minus the minimum observed value within a cruise). The maximum observed ratio of upper slough DOM to lower slough DOM was 10.02 (19 May 2008, between stations 2 and 9) and the minimum 


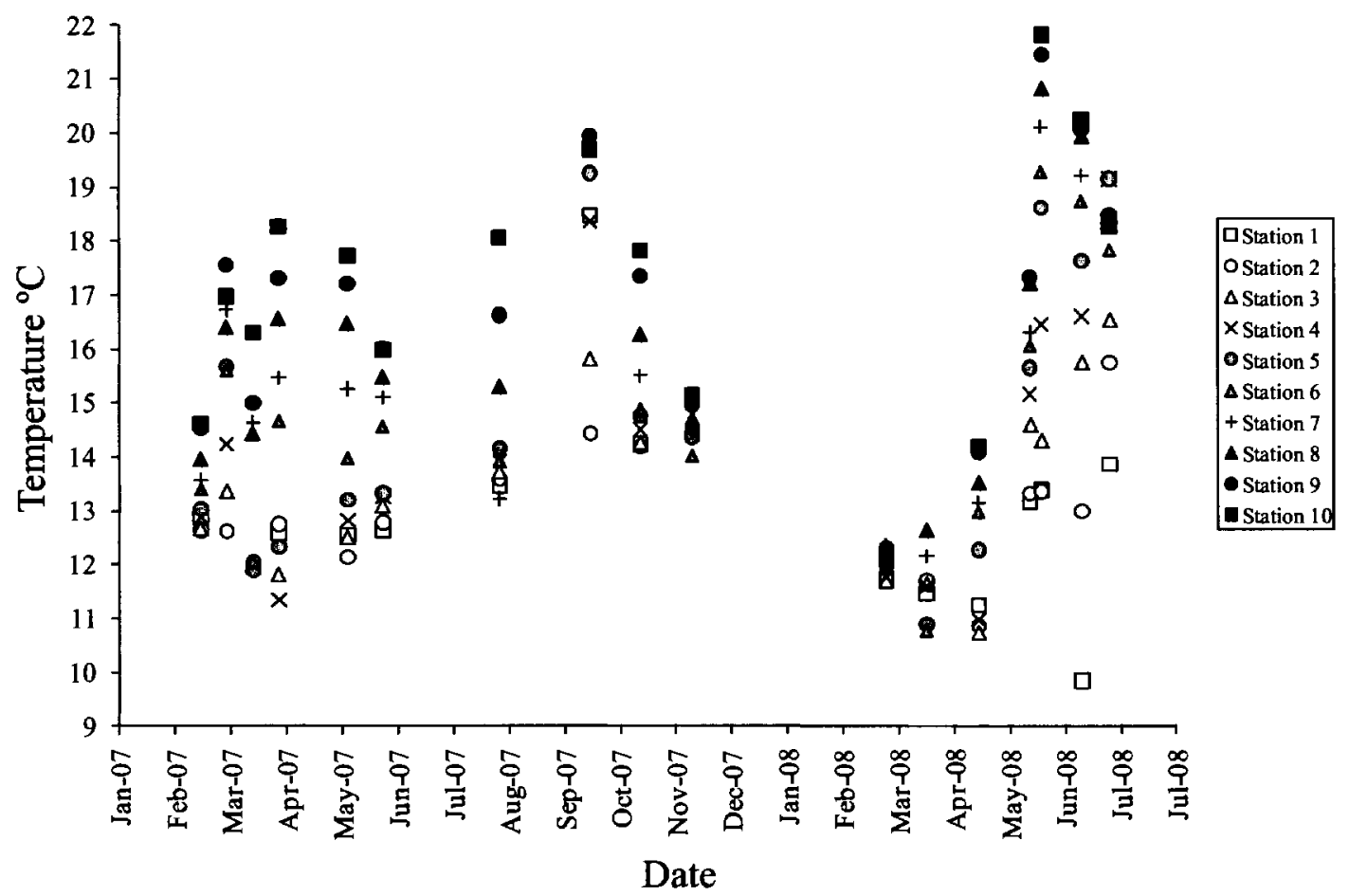

Figure 5. Temperature $\left({ }^{\circ} \mathrm{C}\right)$ at each station for all sampling dates $(2 / 21 / 2007-$ 6/25/2008).

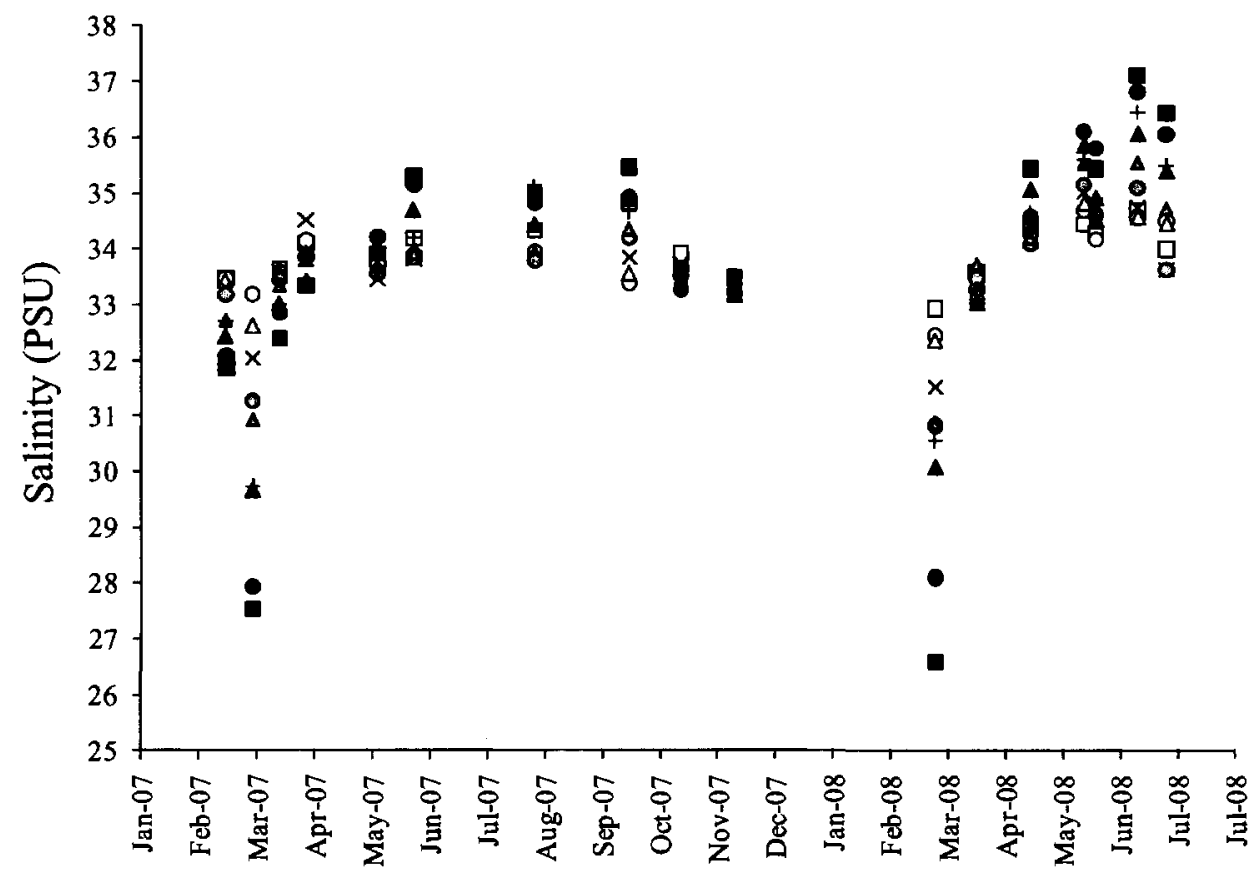

Date

Figure 6. Salinity (PSU) at each station for all sampling dates (2/21/2007 $6 / 25 / 2008$ ). 


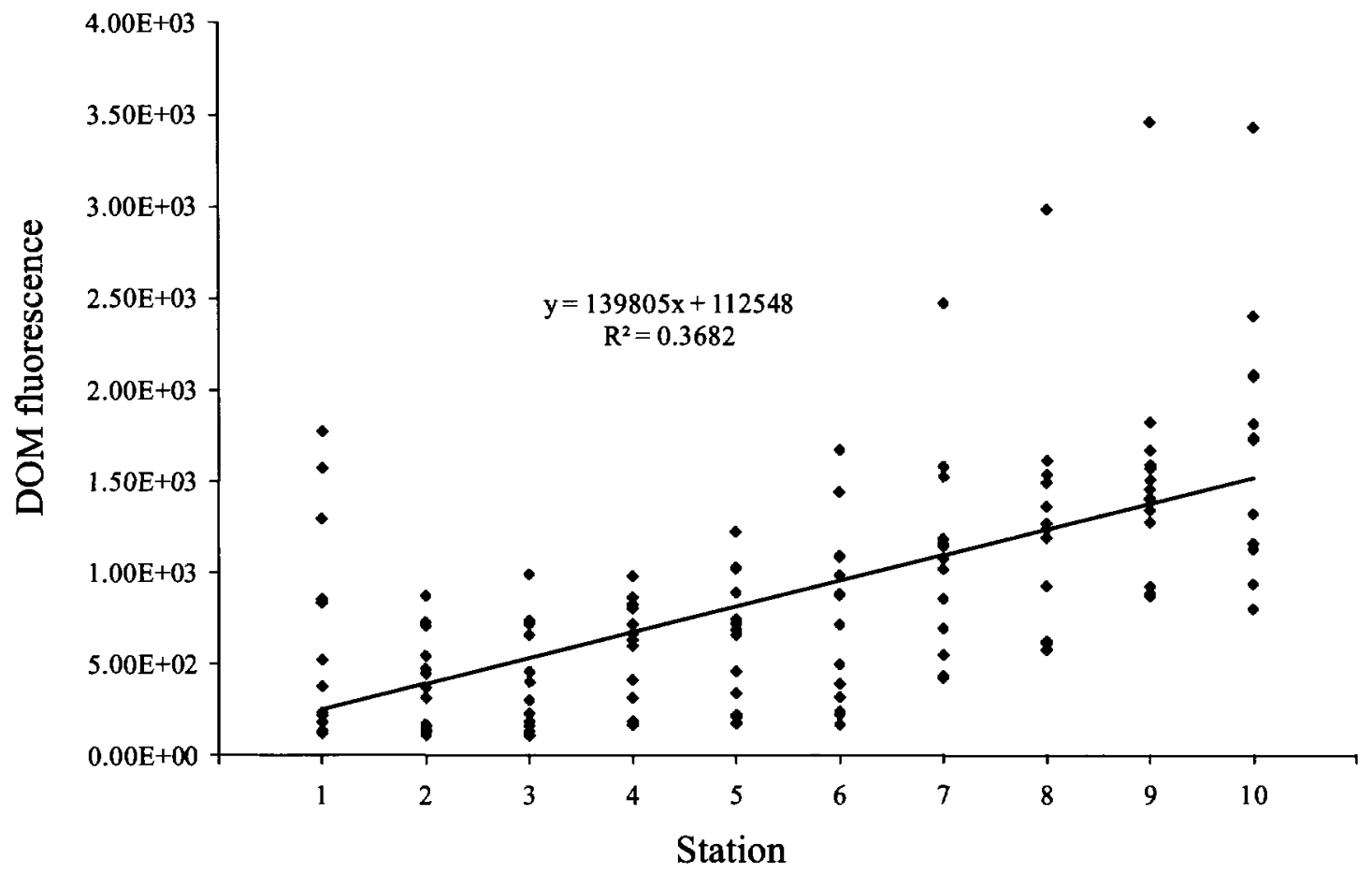

Figure 7. Dissolved organic matter (DOM) at ten stations in Elkhorn Slough. Data represent 12 measurements at each station. Fluorescence units are arbitrary.

Station

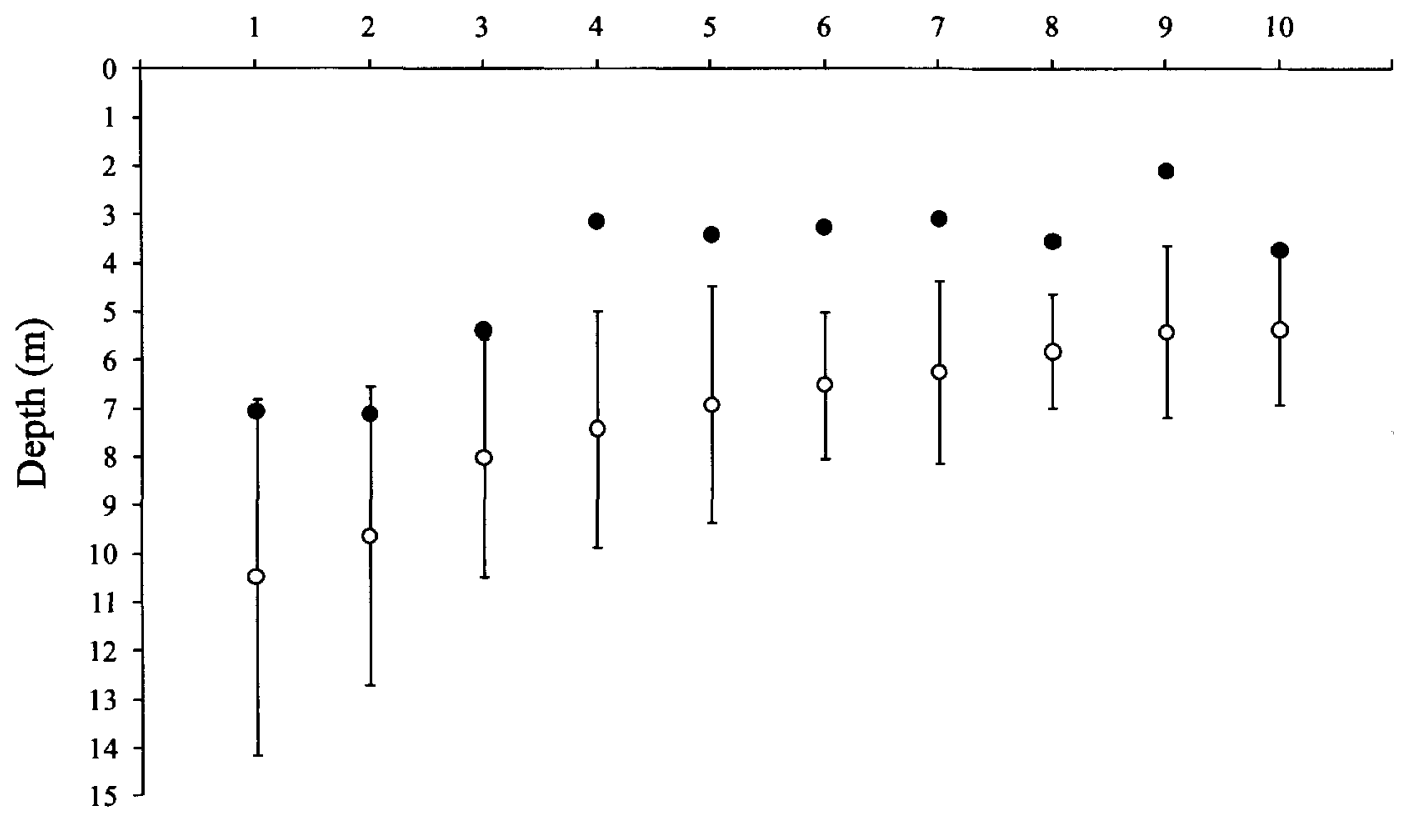

- Bottom Depth O1\%Light Depth

Figure 8. Average $1 \%$ light level $( \pm \mathrm{SD})$ shown with bottom depth at ten stations in Elkhorn Slough. Data represent 16 measurements at each station. 
ratio was 3.06 (13 May 2008, between stations 2 and 9). Measurements of DOM are summarized in Figure 7.

The depth at which light was attenuated to $1 \%$ of surface irradiance (1\% light level) was calculated for each station $(\mathrm{n}=17)$ and is shown in Figure 8. The average $1 \%$ light level is considered to be the compensation depth at which the metabolic demands match photosynthesis. The $1 \%$ light level was always deeper than the bottom depth at all 10 stations indicating no light limitation for photosynthetic organisms throughout Elkhorn Slough.

\section{Phytoplankton community structure of upper Elkhorn Slough}

Upper Elkhorn Slough is characterized by several distinct populations of phytoplankton. Using flow cytometric settings tuned to detect cultures of the cryptophytes Chroomonas sp. (4-6 $\mu \mathrm{m}$ wide x 6-14 $\mu \mathrm{m}$ long) and Cryptomonas sp. $(5 \mu \mathrm{m}$ wide $x 10 \mu \mathrm{m}$ long), three distinct populations (called cryp 1, cryp 2 and cryp 3 ) were detected. These populations were concluded to be cryptophytes due to their large size and characteristic phycobilin fluorescence (Figure 9a). While these populations may be constitutively present in Elkhorn Slough, they were often below concentrations detected optimally with flow cytometry. When cells were present in sufficient densities to allow for flow cytometric detection, the abundance of these three populations increased concomitantly with the ratio of alloxanthin to chlorophyll $a(\mathrm{Chl} a)$ pigment pattern (data not shown). 

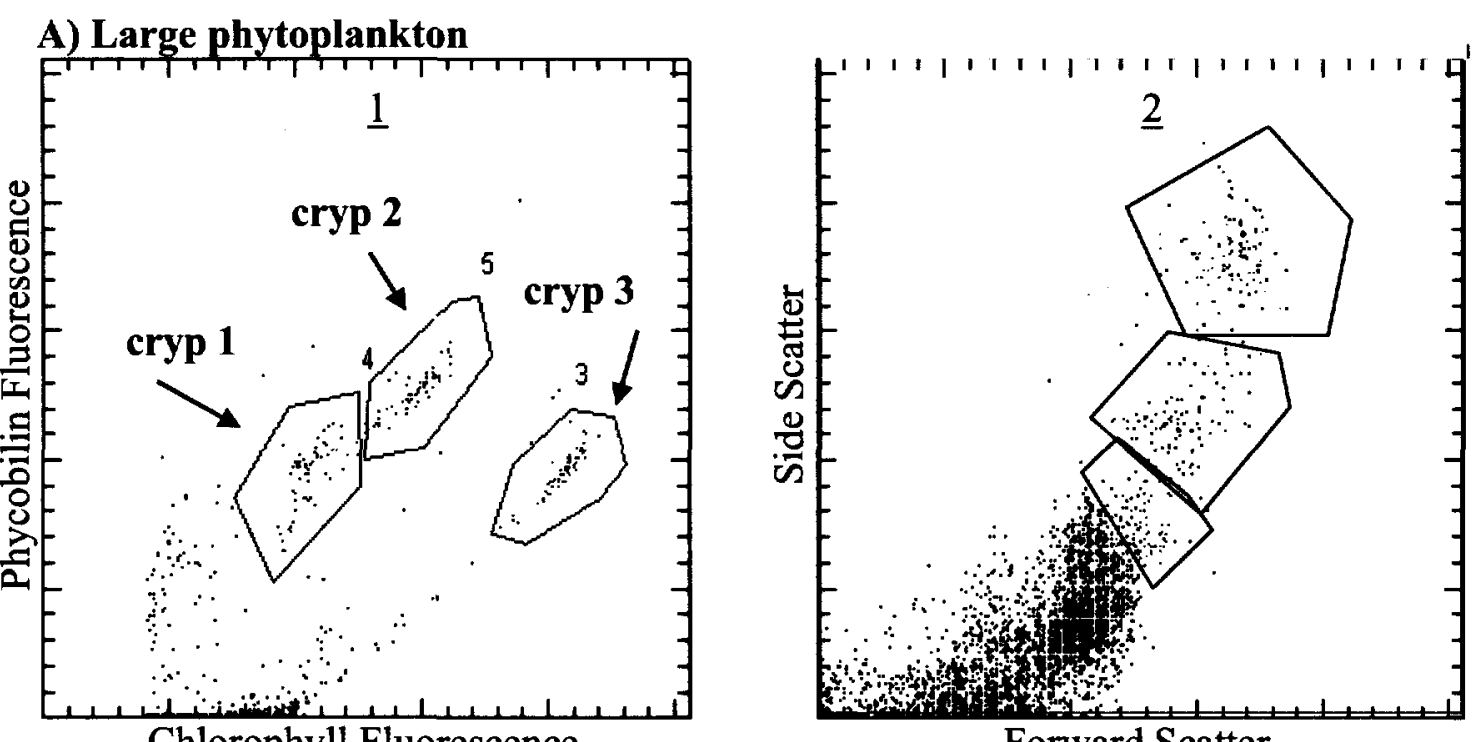

Chlorophyll Fluorescence

Forward Scatter

B) Small phytoplankton

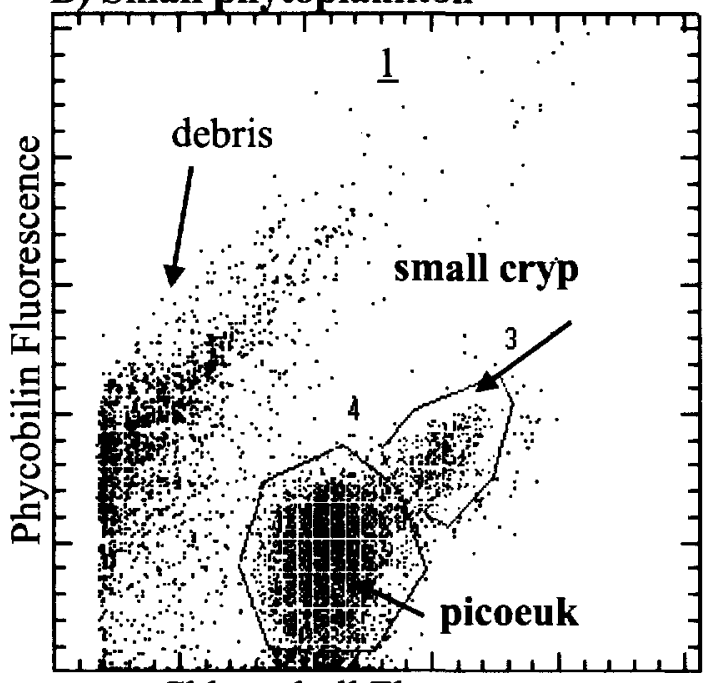

Chlorophyll Fluorescence

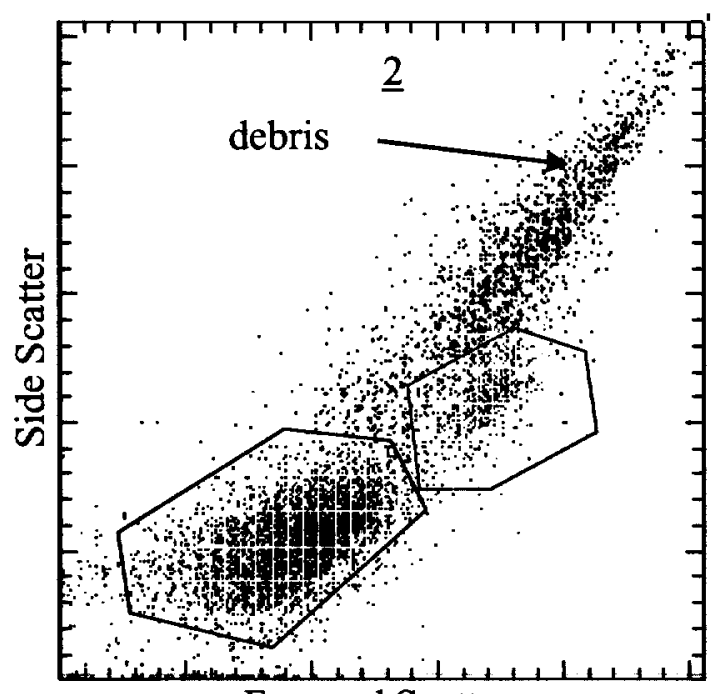

Forward Scatter

Figure 9. Cytograms showing locations of $A$ ) large phytoplankton populations (A instrument settings; Table 5) and B) small phytoplankton populations (B instrument settings). Populations are identified as cryp 1, cryp 2, cryp 3, small cryp and picoeuk on plots 1 and are gated and colored on plot 2 . Axes are arbitrary fluorescence or light scatter units depicted on a log scale. 
Two populations of much smaller cells enumerated with more sensitive instrument settings (B settings; Table 5) were persistently detected in upper Elkhorn Slough (figure 9b). One population was identified as small cryptophytes (due to phycobilin fluorescence) and the other was categorized as picophytoplankton (autofluorescent small cells). The small cryptophyte and picophytoplankton populations were abundant in the upper reaches of the slough and were routinely measured at

concentrations of $5 \times 10^{4}$ cells ml $^{-1}$ and $5 \times 10^{5}$ cells ml $^{-1}$ respectively (Figure 10). Absolute maximum abundance was variable and data likely represent the effect of tidal height at time of sampling rather than true seasonal abundance. Though total abundance varied, when the abundance is normalized to the maximum value within a cruise, it is evident that both populations are structured in a pattern consistent with the observed pigment gradient (Figures 2, 11).

\section{Size fractionation of upper Elkhorn Slough phytoplankton}

The cryp 1, cryp 2 and cryp 3 populations present in Elkhorn Slough were relatively large as detected with flow cytometry, but size fractionation analysis was conducted to quantitatively constrain the size classes. The cryp 3 population was larger than $10 \mu \mathrm{m}$ in all dimensions since it was removed entirely from the filtrate by the $10-\mu \mathrm{m}$ prefiltration. The cryp 2 and cryp 3 populations were reduced to less than $20 \%$ of the initial concentration by the $3-\mu \mathrm{m}$ prefiltration and completely by the $1-\mu \mathrm{m}$ prefiltration indicating that the mean size of both of these populations are between 3-10 $\mu \mathrm{m}$. The 3$\mu \mathrm{m}$ filtration reduced the small cryptophyte population by only $39 \%$, therefore the 


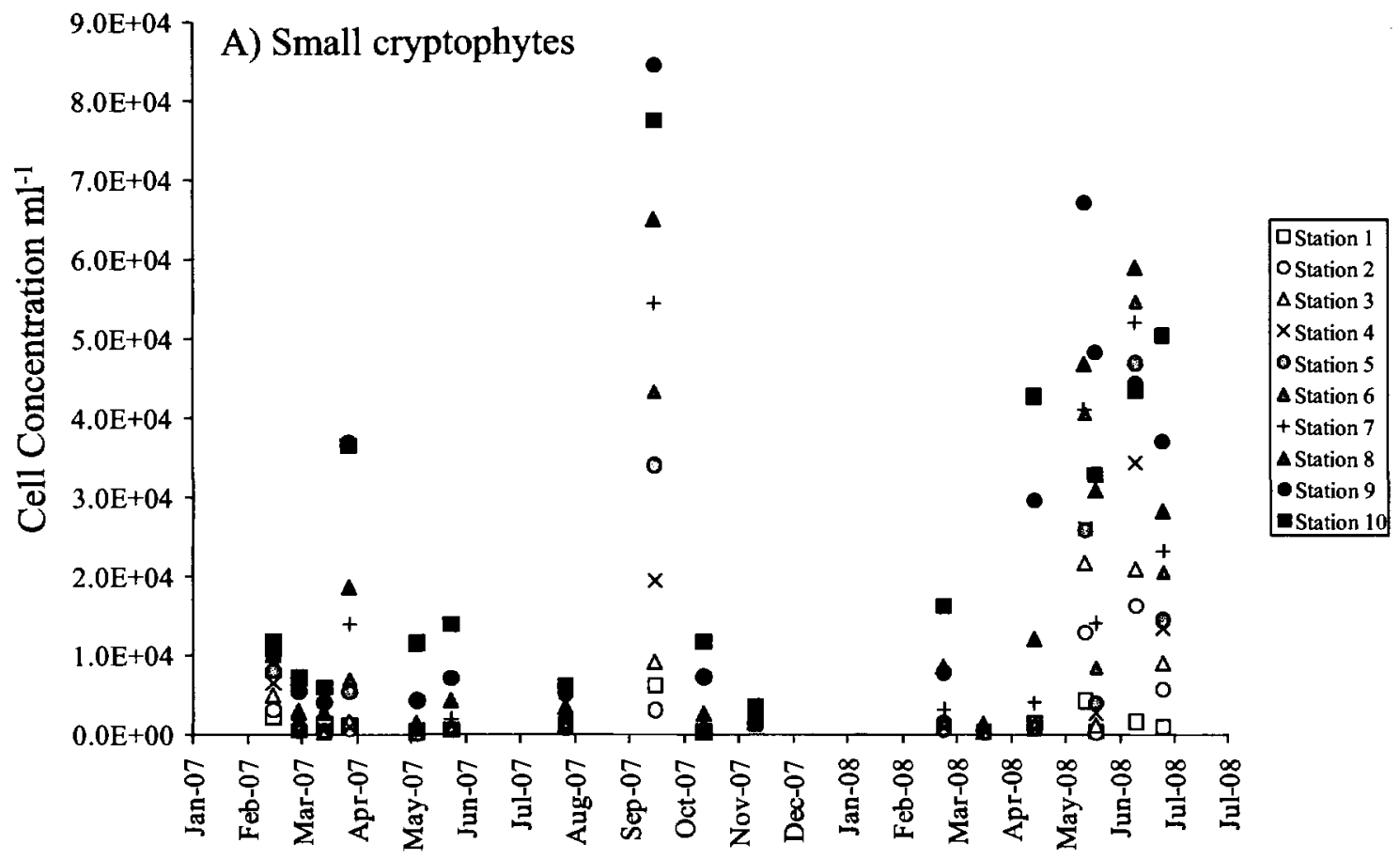

Date

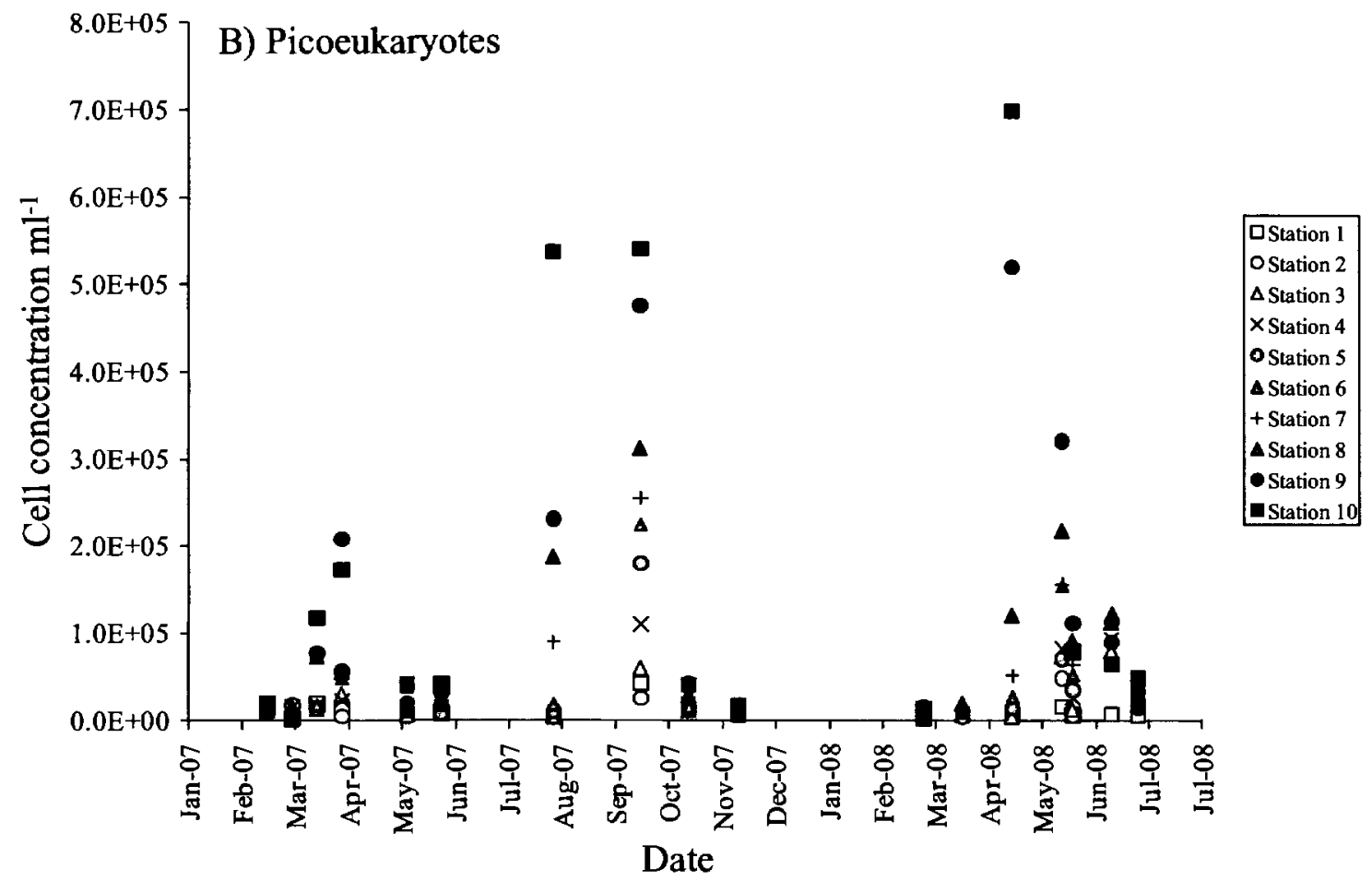

Figure 10. Cell concentrations of A) small cryptophytes and B) picoeukaryotes at 10 stations in Elkhorn Slough throughout sampling period. 

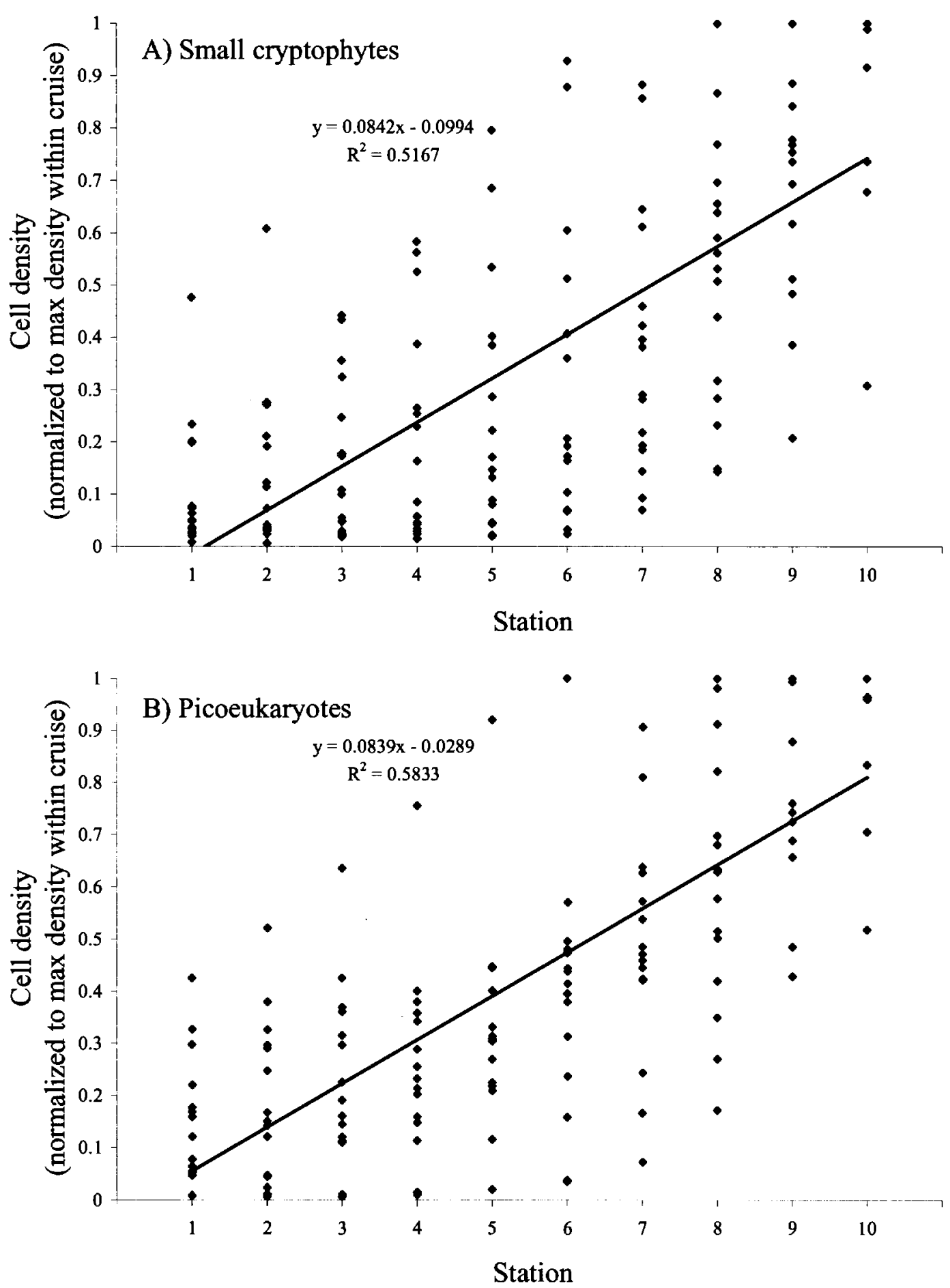

Figure 11. Cell density pattern of A) small cryptophytes and B) picoeukaryotes in Elkhorn Slough. Data represent measurements of cell concentration at each station $(n=15)$ normalized to maximum density within sampling date. 
majority of the cells passed through the $3-\mu \mathrm{m}$ filter and are smaller than $3 \mu \mathrm{m}$ in at least one dimension. The majority of the small cryptophytes are less than $5 \mu \mathrm{m}$ since $74 \%$ of the cells passed through. Finally, cells in the small picophytoplankton category were only reduced significantly by the $1-\mu \mathrm{m}$ prefilter indicating these cells fall in the range of $1-3 \mu \mathrm{m}$ (Figure 12).

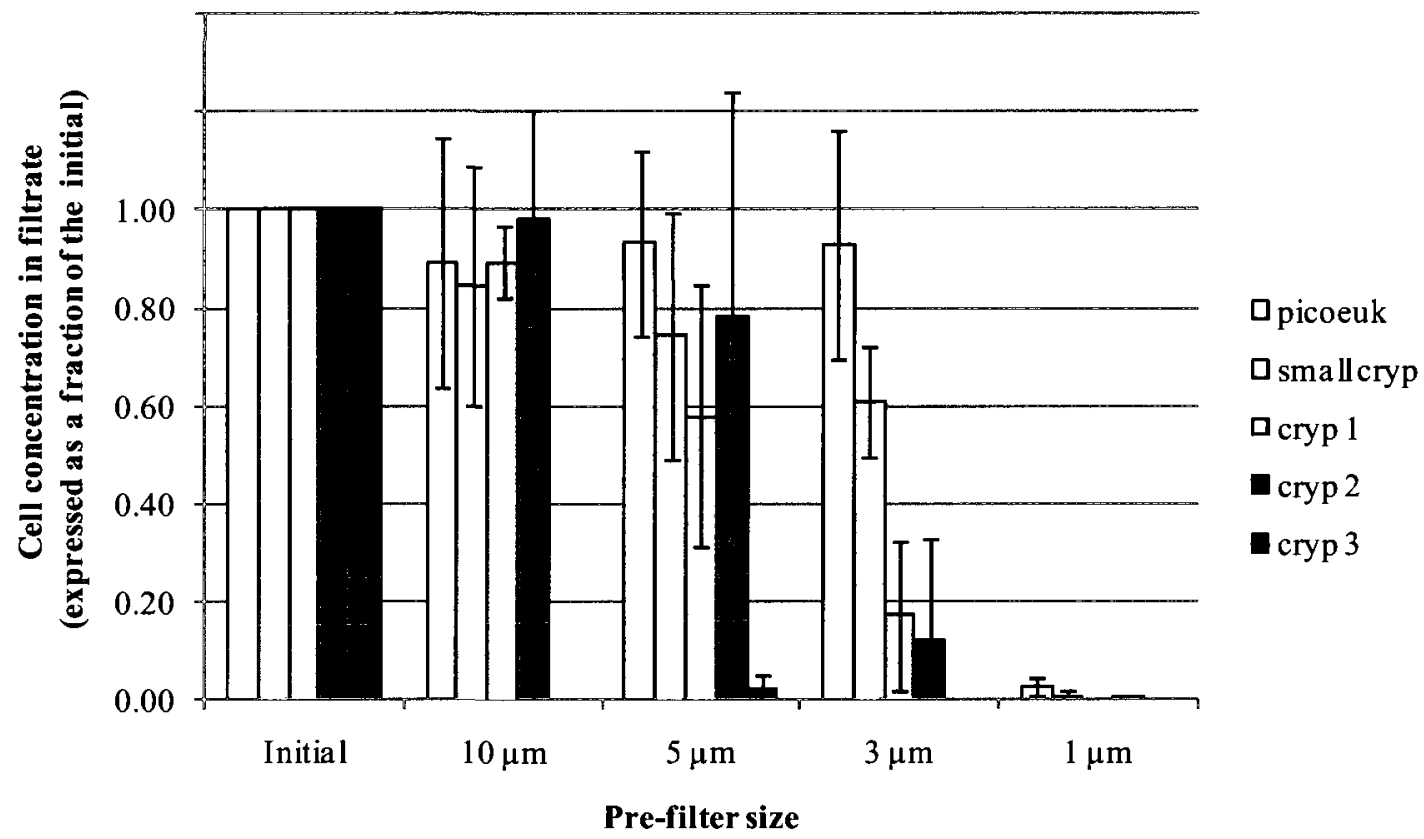

Figure 12. Flow cytometric analysis of Elkhorn Slough phytoplankton populations after size fractionation. Cell concentration is expressed as the fraction of cells in the filtrate of four pre-filter sizes $(10,5,3$ and $1 \mu \mathrm{m})$ relative to the initial. Data represent an $n=6$ and are shown \pm SD.

Size fractionated Chl $a$ concentrations indicate that the photosynthetic biomass of Elkhorn Slough is dominated by the small size classes. Of the total Chl $a, 81-88 \%$ is in the $<3 \mu \mathrm{m}$ size class and $4-10 \%$ is in the $3-5 \mu \mathrm{m}$ size class (Figure 13 ).

Epi-fluorescent microscopic analysis detected the presence of large cryptophytes, however the three populations observed with flow cytometry were visually 


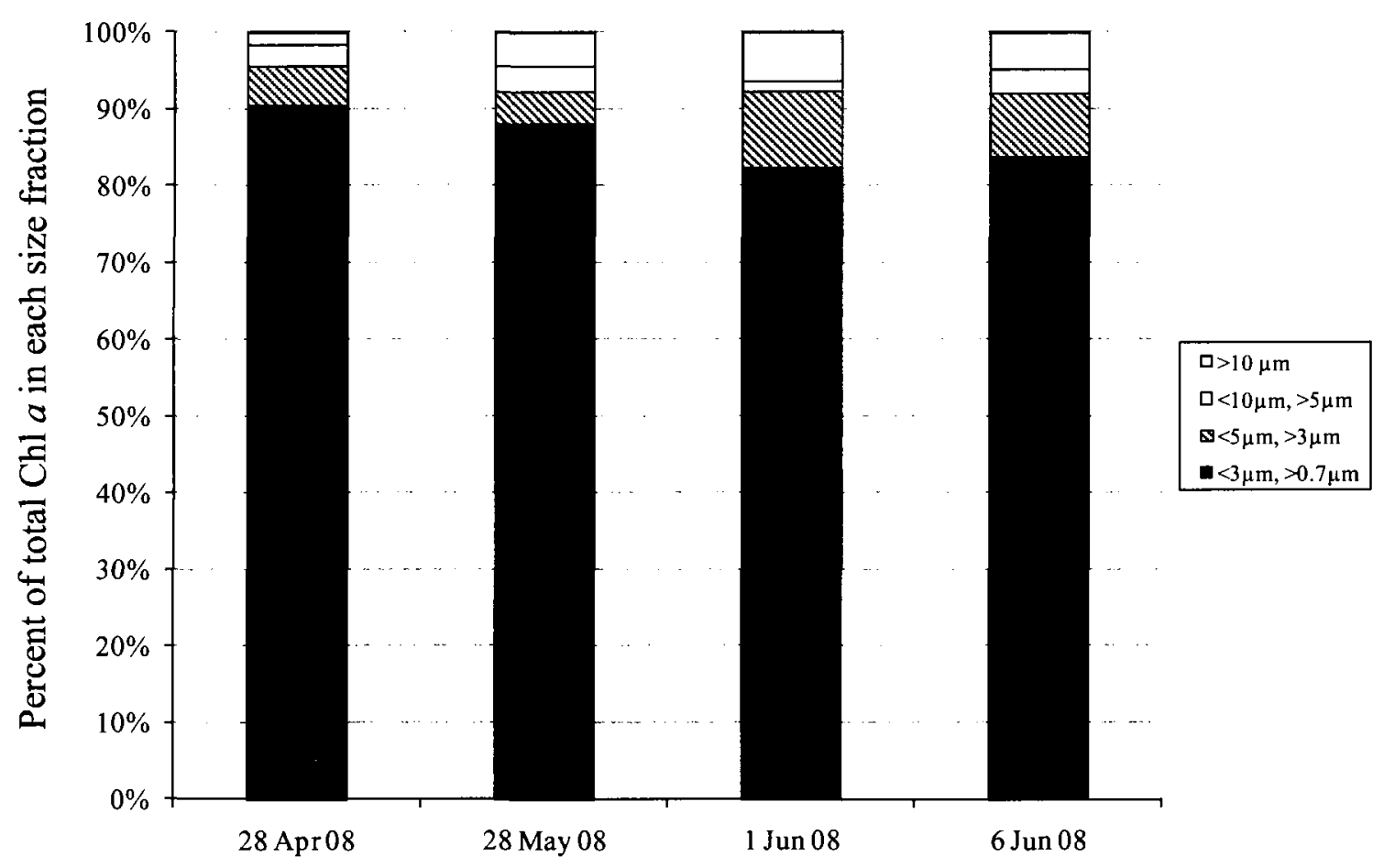

Sample Date

Figure 13 Size fractionated biomass ( $\mathrm{Chl} a$ ) in upper Elkhorn Slough. Chl $a$ content of each size fraction is expressed as a percentage of total Chl $a$.

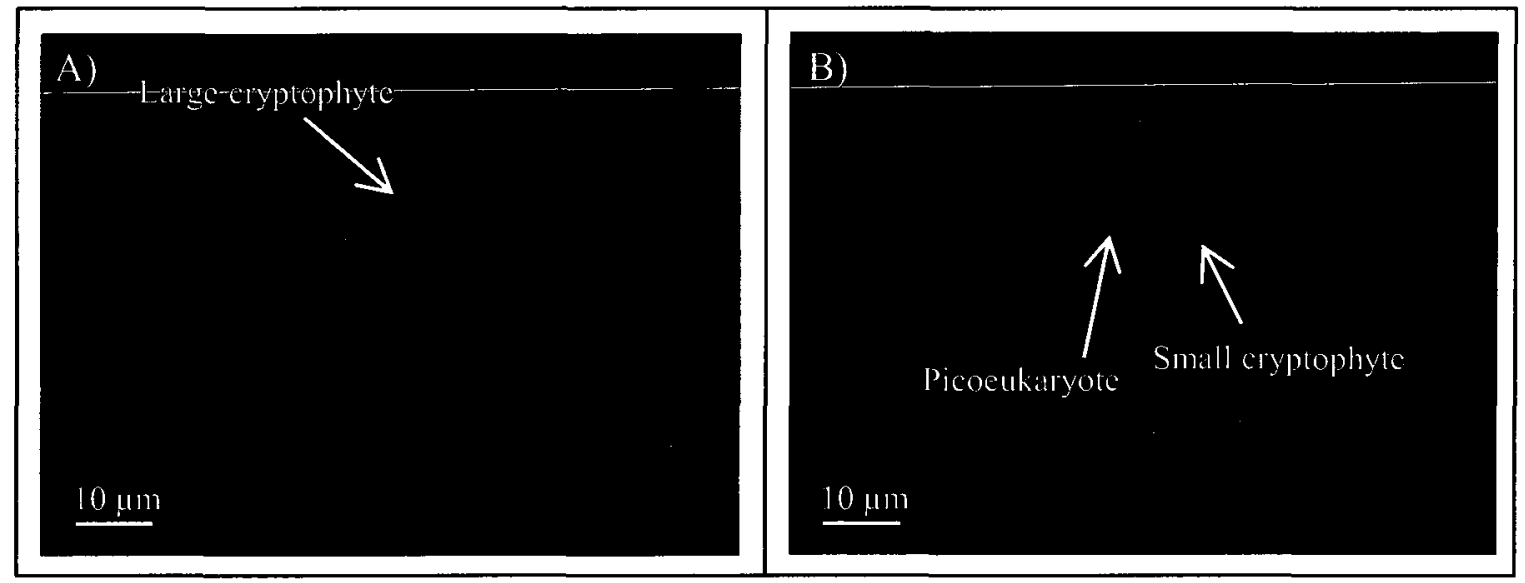

Figure 14. Epifluorescence micrographs of Elkhorn Slough A) large cryptophytes and B) small cryptophytes and picoeukaryotes. 
indistinguishable though some variability in size was noted (Figure 14a). Microscopic analysis of the 5- $\mu \mathrm{m}$ filtrate showed abundant small picophytoplankton largely comprised of prymnesiophte and prasinophyte eukaryotes. The small cryptophytes were also visible under epi-fluorescence and were discriminated by their orange fluorescence and larger size (Figure 14b).

\section{Vital stain protocols, performance and verification}

a. Killed phytoplankton experiments

i. ${ }^{14} \mathrm{C}$ incorporation experiments

Dilutions of phytoplankton with low fractions of ultraviolet light-killed dead cells (high fraction live cells) as determined with SYTOX Green corresponded to high levels of production per cell. As fraction dead cells increased, production per cell rate decreased in a tight linear relationship for two separate experiments (Figure 15). In this experimental setup with contrived fractions of live and dead cells, SYTOX Green accurately tracked dead cells as

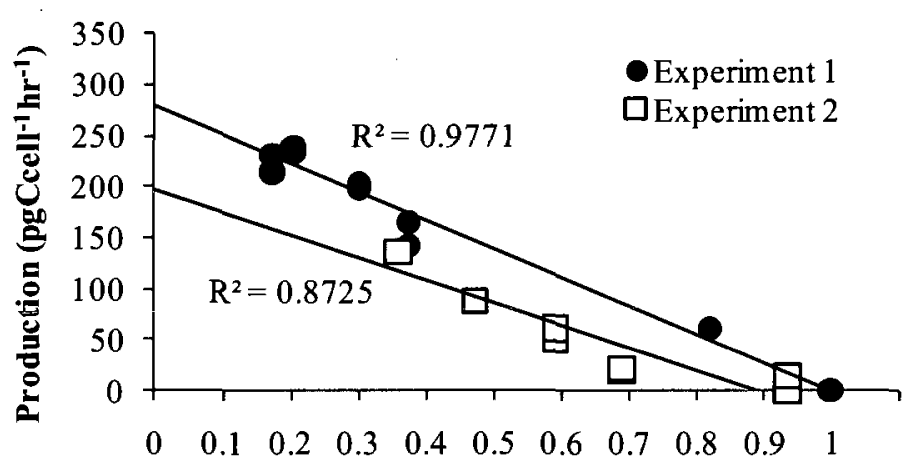

Fraction Dead (SYTOX)

Figure 15. Verification of SYTOX Green fraction dead in Dunaliella sp. with cell-specific production rate. Data represent two experiments each with two replicates shown as individual points. When only one replicate is visible they are overlapping.

verified by photosynthetic rate. 
ii. Cell digestion vs. SYTOX Green: Ultraviolet light killed cells

The fractions of viable cells as determined by the cell digestion assay and SYTOX Green were compared in freshly killed (with ultraviolet light) fractions of Dunaliella sp. SYTOX Green staining showed a clear relationship with the expected dead fraction (slope $=0.83, \mathrm{R}^{2}=0.98$ ). It was expected that membrane-permeable cells as determined by SYTOX Green would be permeable to digestion, however the cell digestion assay did not reduce cell counts relative to the control in any of the five fractions examined. The heat treatment alone (without digestive enzymes) also did not reduce total cell counts.

b. Natural cell death: Senescent culture experiments

i. Cell Digestion vs. SYTOX Green: natural cell death

Three senescent cultures (Dunaliella sp., Phaeodactylum sp., Cryptomonas sp.) were assayed for viable and non-viable cells with cell digestion and SYTOX Green. There was reasonable agreement between both assays when estimating fraction live cells in senescent cultures (Table 6). The cryptomonad culture had very few dead cells as determined by both methods.

Table 6. Comparison of estimates of dead cells in senescent algal cultures obtained with the cell digestion assay and SYTOX Green.

\begin{tabular}{lcccc}
\hline Culture & $\begin{array}{c}\text { Total } \\
\text { Counts } \\
\left(\text { cells ml } \mathrm{m}^{-1}\right)\end{array}$ & $\begin{array}{c}\text { Cell Digest } \\
\text { Counts } \\
\left(\text { cells ml }{ }^{-1}\right)\end{array}$ & $\begin{array}{c}\text { \% Dead Cells } \\
\text { Cell Digestion Assay }\end{array}$ & $\begin{array}{c}\text { \% Dead Cells } \\
\text { SYTOX Green }\end{array}$ \\
\hline Cryptomonas $\mathrm{sp}$. & $3.6 \times 10^{5}$ & $3.9 \times 10^{5}$ & $-11 \% *$ & $1 \%$ \\
\hline Dunaliella $\mathrm{sp}$. & $7.8 \times 10^{5}$ & $6.8 \times 10^{5}$ & $12 \%$ & $2 \%$ \\
\hline Phaeodactylum $\mathrm{sp}$. & $4.1 \times 10^{6}$ & $2.4 \times 10^{6}$ & $42 \%$ & $50 \%$ \\
\hline
\end{tabular}

* Resulting from variability in cytometric counts 

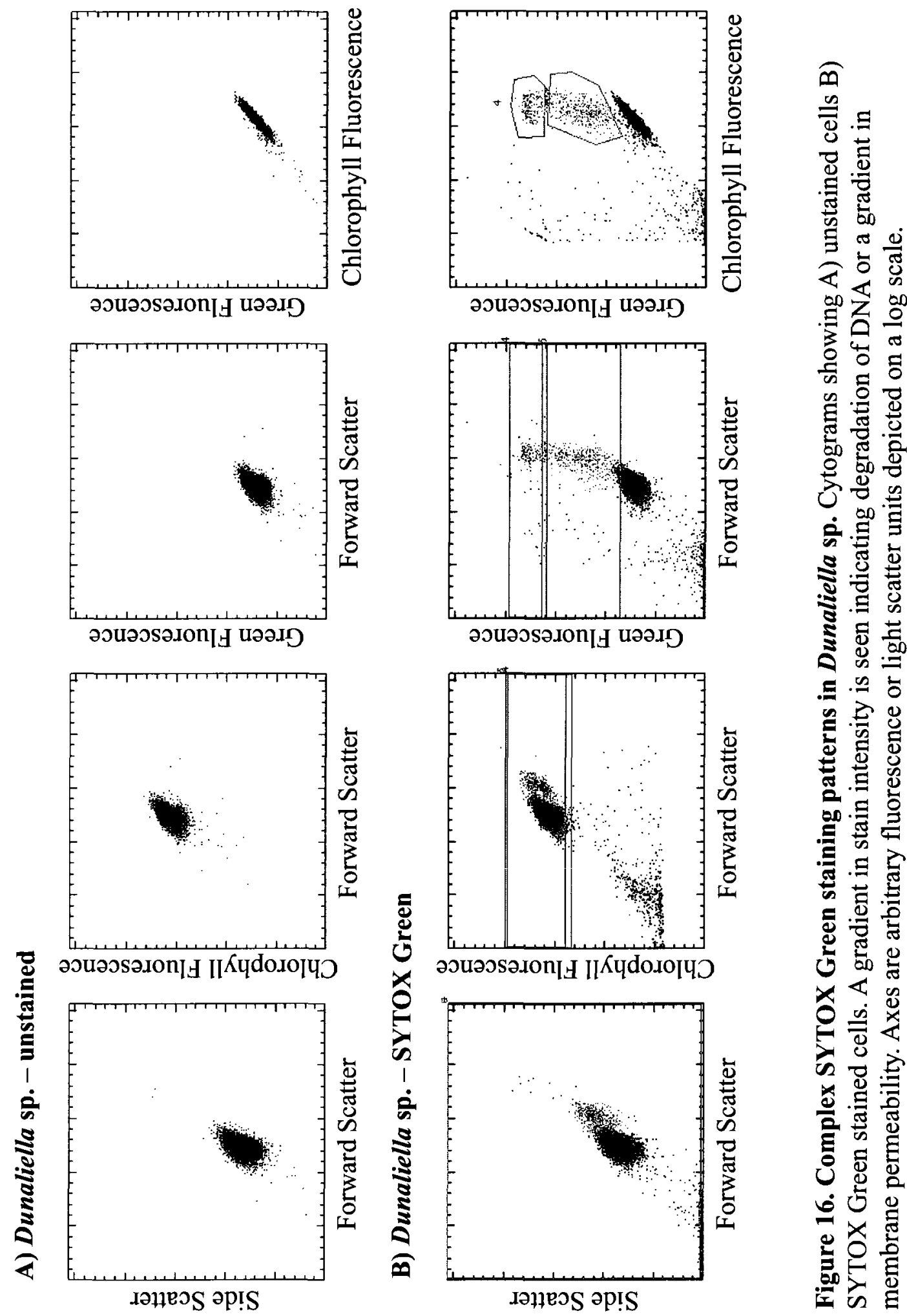

층으

类

की

ผ 을

矛

o 50

से

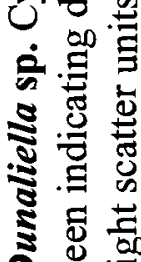

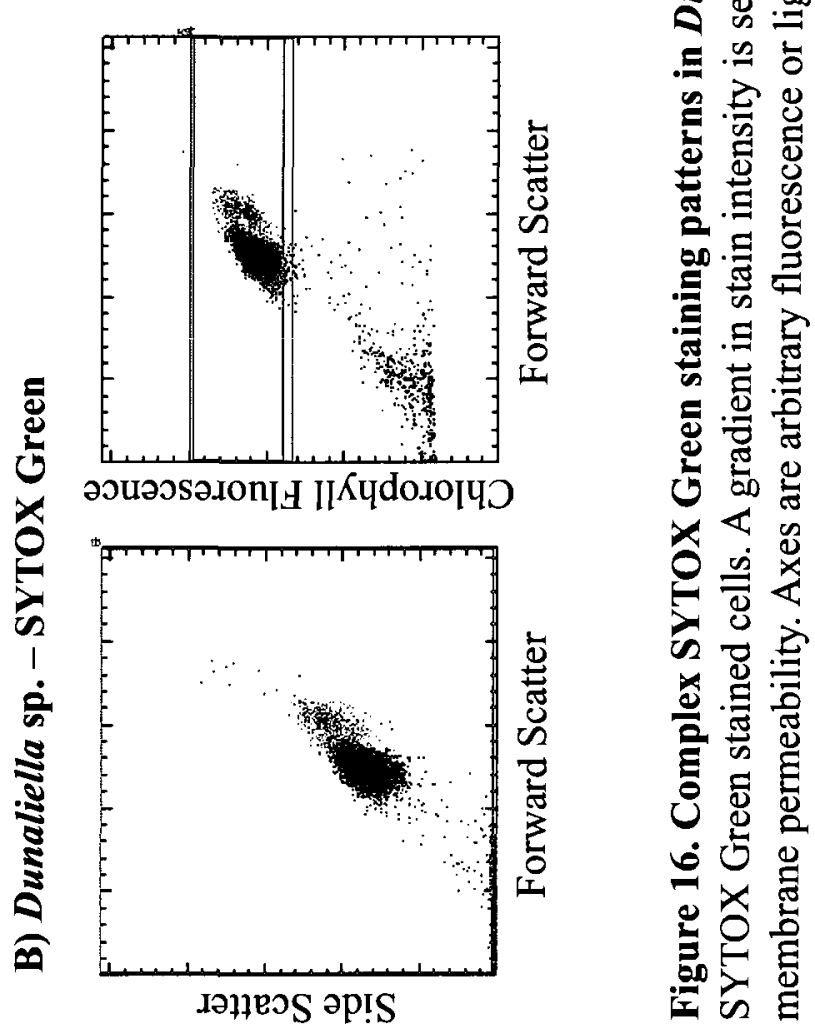



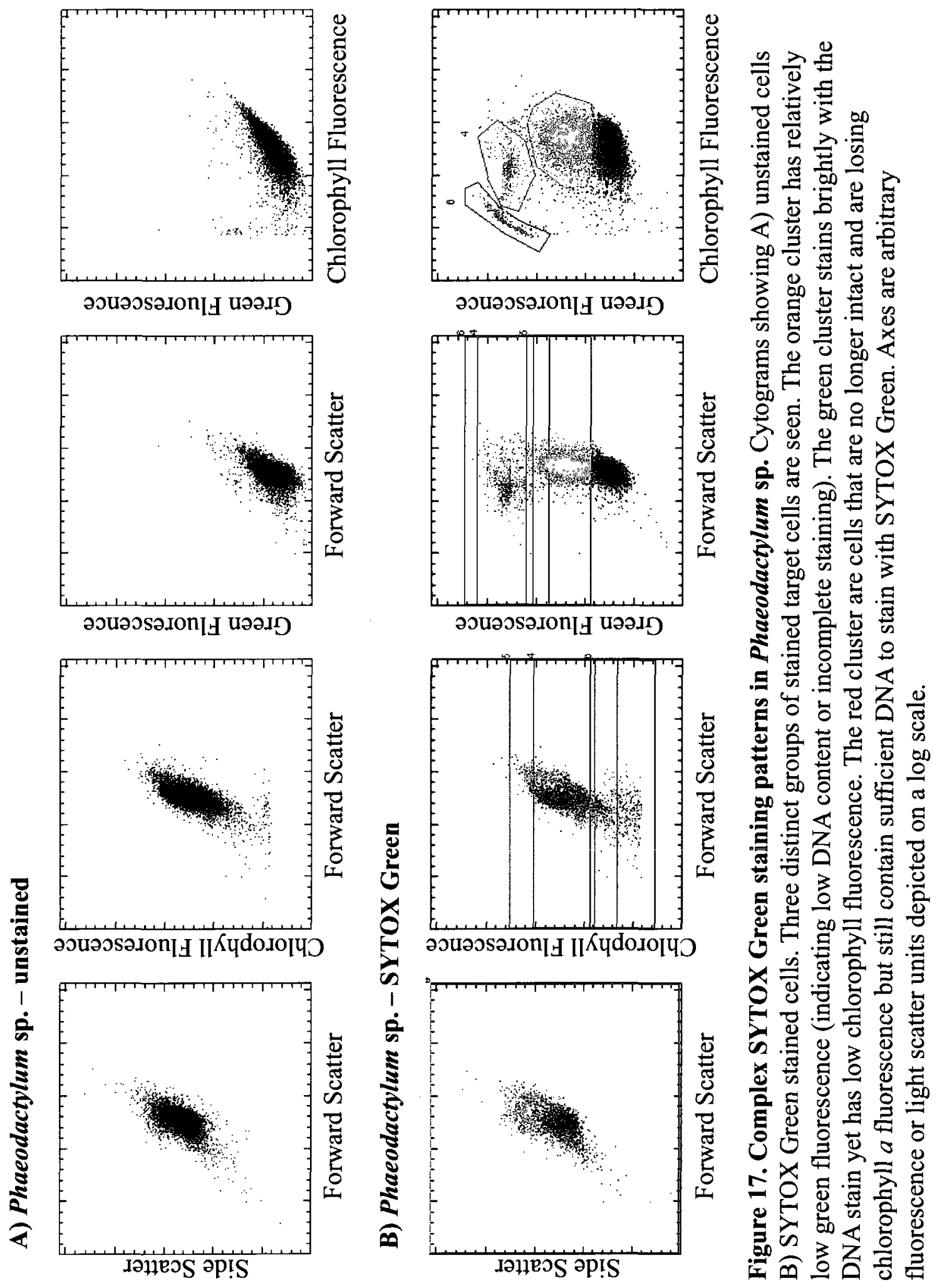
Interpretation of staining in both Dunaliella and Phaeodactylum cultures was difficult as there were complex patterns in stain uptake (Figures 16, 17). Since SYTOX Green is a DNA stain, complex staining patterns may result from variable degradation in DNA and chlorophyll content of otherwise intact cells or incomplete permeability of cell membranes. With the cell digestion assay, there were no ambiguities in interpretation of stain intensity and the heat treatment alone did not significantly reduce cell counts in senescent cultures (data not shown). The cell digestion treatment and heat treatment control did however alter the orange fluorescence signal of the cryptomonad (Figure 18). If this were to happen in a natural sample, the target cells may no longer have an optical signature allowing for clear detection which would obscure interpretation of vital data.

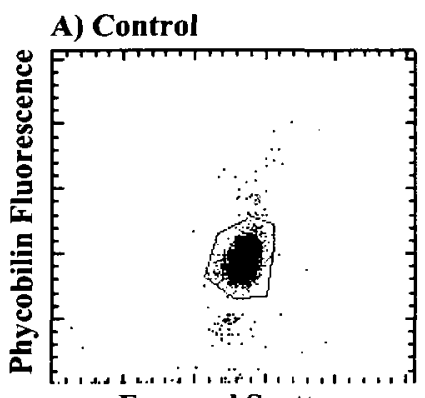

Forward Scatter

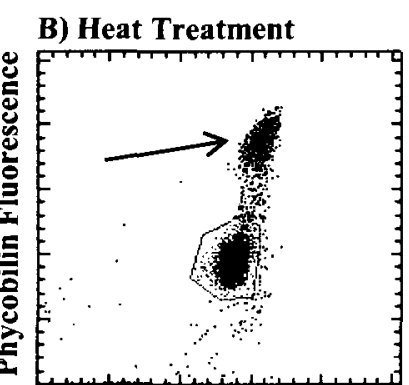

Forward Scatter

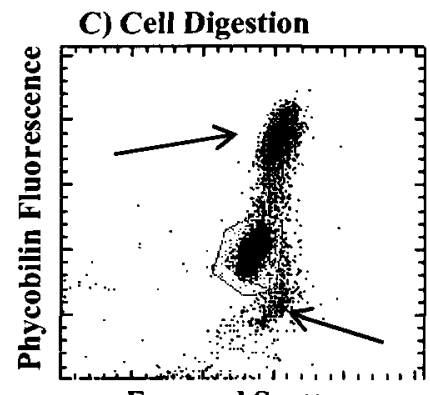

Forward Scatter

Figure 18. The effect of cell digestion and heat treatment on the optical properties of Chroomonas sp. phytoplankton cells. The control exhibits normal phycobilin fluorescence whereas a fraction of the population shows a 100x increase due to $B$ ) heat treatment and C) cell digestion as indicated with arrows. Note the presence of partially digested cells. Axes are arbitrary fluorescence or light scatter units depicted on a log scale.

c. Vital assay performance on environmental samples

All three vital assays were tested in environmental samples to identify any potential complications. The cell digestion assay was determined to be inappropriate for 
use in Elkhorn Slough on the target population of cryptophytes as the heat treatment alone (without digestive enzymes) reduced cell counts by $16-36 \%$. Furthermore, natural samples exposed to lethal levels of ultraviolet light were incompletely digested while the expectation is they would be digested completely. SYTOX Green was determined to be inappropriate for use in Elkhorn Slough due to high levels of non-specific staining that increased the event count beyond the optimal threshold ( $>1000$ events $\mathrm{s}^{-1}$; Figure 19). Cells remaining in the unstained target location after SYTOX Green addition, presumably live cells, exceeded the total count in unstained samples by sometimes two times. SYTOX Green was tested in algal cultures inoculated with test dust particles to determine if abiotic particulates in Elkhorn Slough are responsible for the high background staining. It was found that unstained cells were counted without interference in the presence of test dust, however when SYTOX stain was added, the event rate increased beyond the detection limit and inhibited accurate counting of the target cells. Fluorescein diacetate (FDA) showed no non-specific background staining and was deemed appropriate for use in turbid, sediment-laden environments.

For vital staining with FDA, small cryptophytes were gated on the basis of forward scatter and chlorophyll fluorescence as the spectral overlap of the green fluorescence into the orange channel inhibited clean gating and detection with the ideal parameters (FL3, FL2). On the basis of forward scatter and chlorophyll fluorescence alone, the picoeukaryote cluster was non homogenous and contained Synechococcus sp. cells, a population showing the opposite pattern in distribution and abundance (Figure 4). Because of this, staining patterns of picoeukaryotes could not be interpreted. Small 

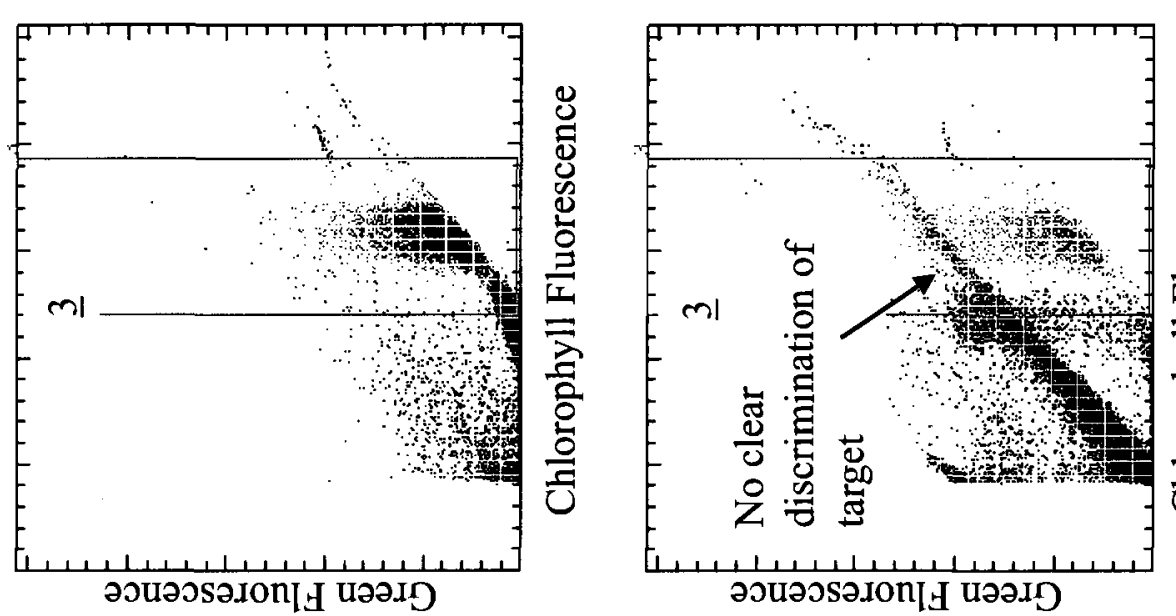

超芯哭

吅幽.

용으.

号苍苛

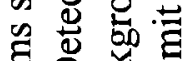

寻号是

แू

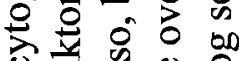

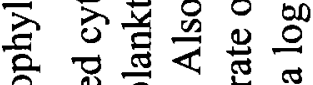

응

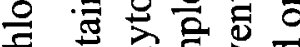

号䓃㤩总

ช.
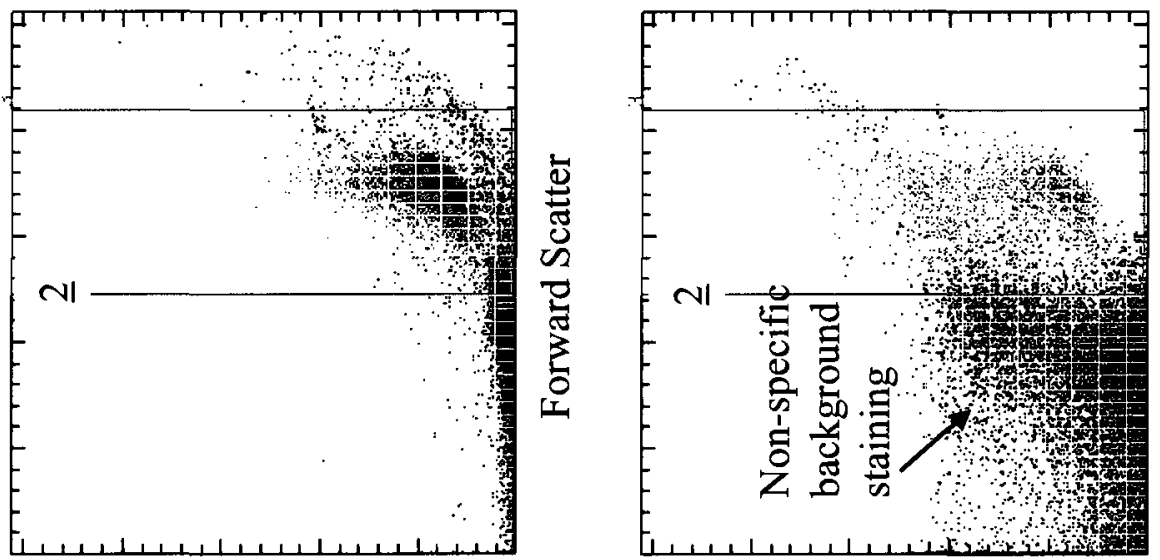

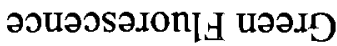
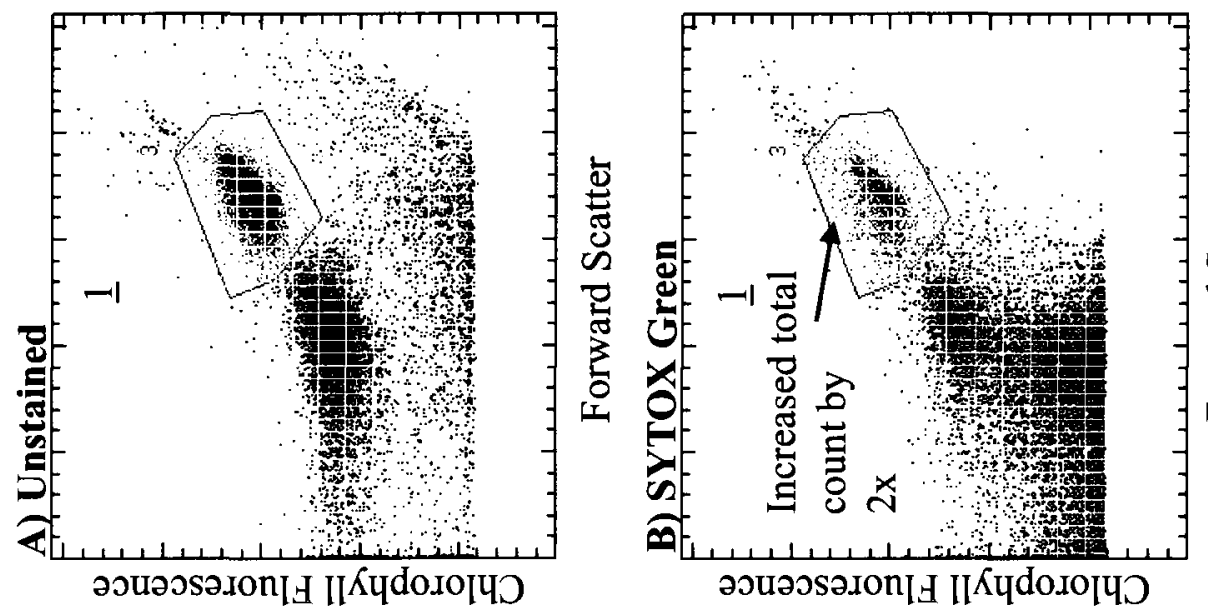

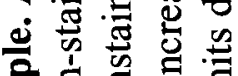

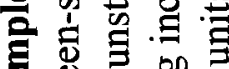

幽

$\approx$

岕

- 0 鬲

$\xi \frac{\pi}{2}$ 을

- 的宁

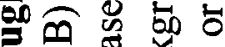

욯

๙

느믈

幽艺

덩ㅇㅇㅛ

용

=

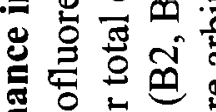

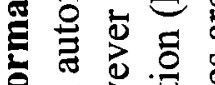

흐

30

형 \&

용

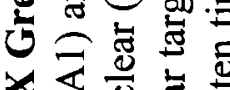

$0 \leqslant \frac{1}{0}$ 光

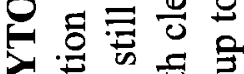

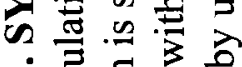

음 뭉용

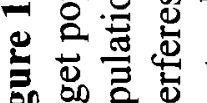

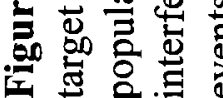


A) Unstained Elkhorn Slough (Station 10)

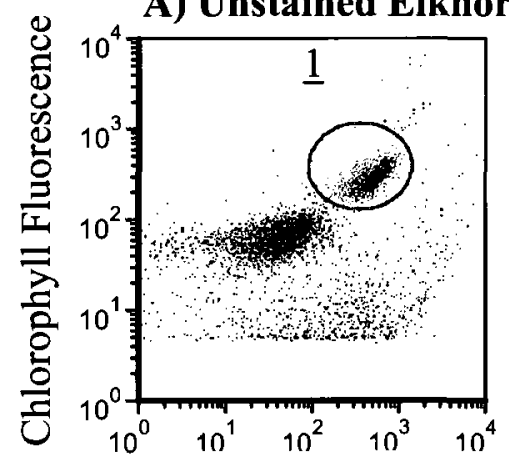

Forward Scatter

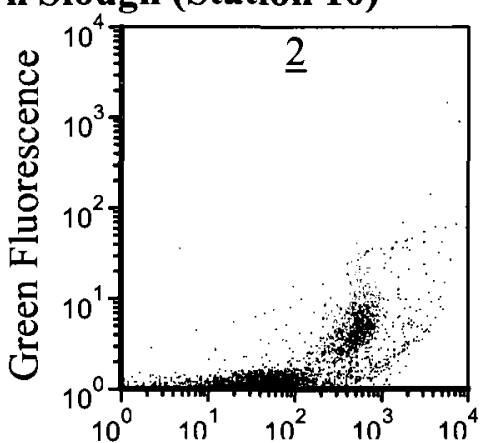

Forward Scatter

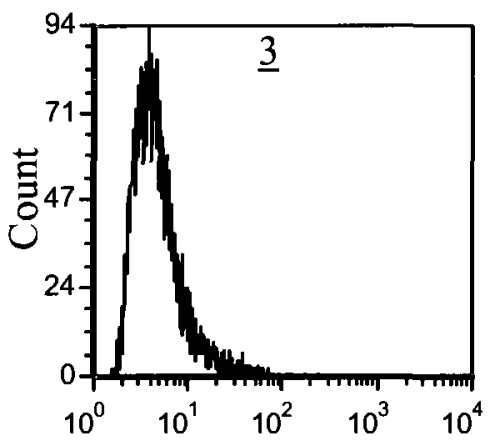

Green Fluorescence

B) Upper Elkhorn Slough (Station 10)

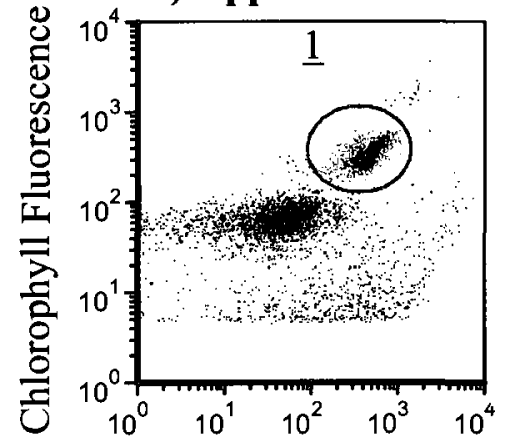

Forward Scatter

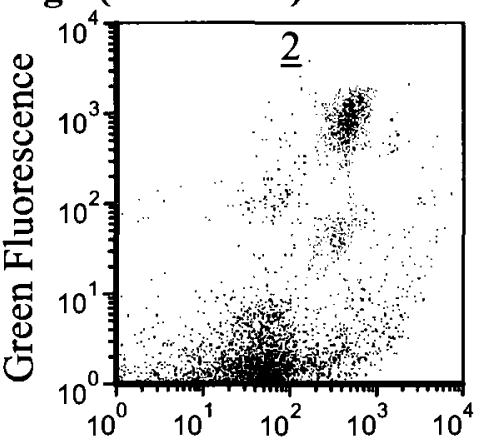

Forward Scatter

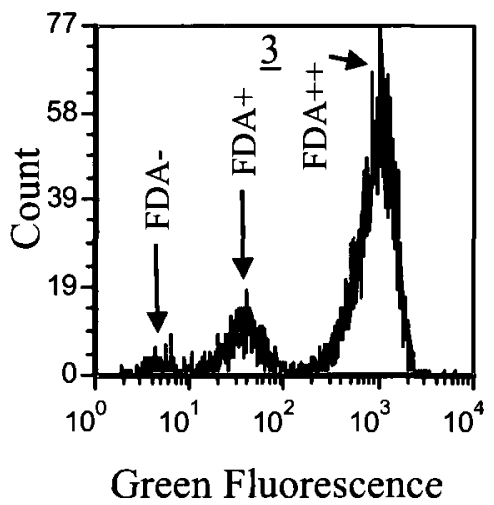

C) Mid Elkhorn Slough (Station 5)

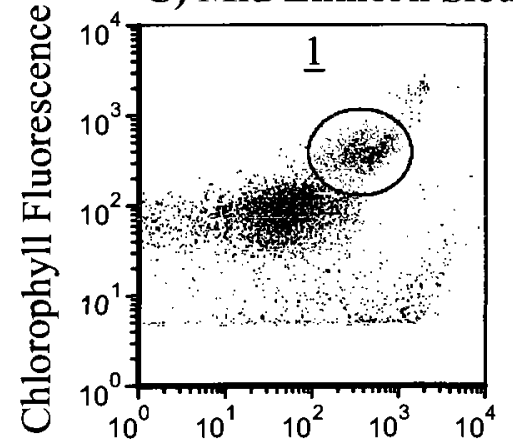

Forward Scatter

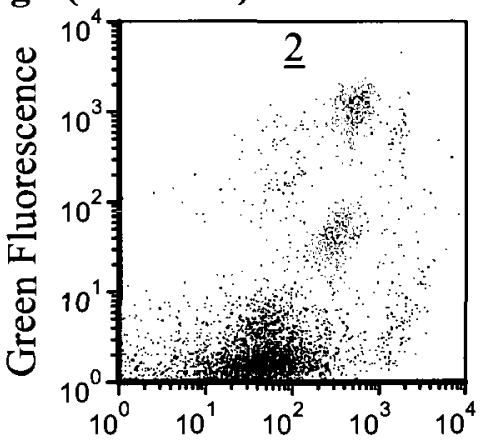

Forward Scatter

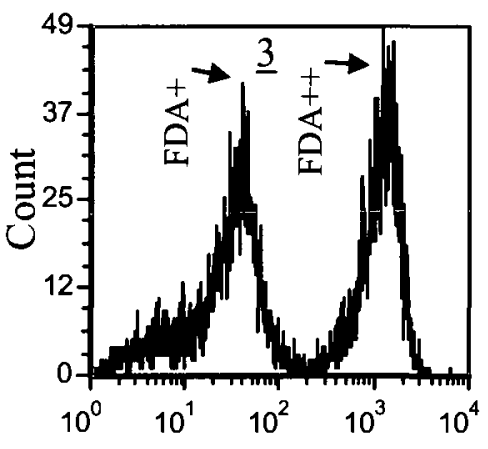

Green Fluorescence

Figure 20. FDA response of small cryptophyte algae in Elkhorn Slough. The small cryptophyte population is gated in an unstained control sample from station 10 (A1) and is shown with green autofluorescence (A2) which is then plotted as a histogram (A3). Station 10 small cryptophytes are gated on the basis of autofluorescence (B1) and shown with green FDA fluorescence (B2) which is presented as histogram (B3) where three distinct metabolic responses are labeled. Small cryptophytes from station 5 are plotted based on autofluorescence (C1) and with FDA stain added (C2). Finally, a histogram of station 5 cells illustrates a decrease in the relative abundance of FDA++ cells. Axes are arbitrary fluorescence or light scatter units depicted on a log scale. 
cryptophytes were however able to be gated on the basis of forward scatter and chlorophyll alone, and were therefore suitable for FDA uptake analysis.

Three distinct FDA fluorescence responses were seen in the small cryptophyte population. A subset became highly fluorescent green (FDA++, approximately 1000 -fold increase in FL1), an additional subset became moderately fluorescent (FDA+, approximately 100-fold increase in FL1) and a subset remained non-fluorescent (FDA-, no or little increase in FL1; Figure 20).

Since there are widely variable incubation times reported in the literature for FDA, optimal stain time was determined through monitoring FL1 of the target cells throughout a two hour period. Within $30 \mathrm{~s}$, detection of the three FDA fluorescence responses was possible with fluorescence saturation in the FDA++ fraction occurring after $10 \mathrm{~min}$. The average value for each particle in the three response categories was measured over a period of 2 hours (Figure 21a). Cells in the FDA- category exhibited a slow increase in green FDA fluorescence over the first $40 \mathrm{~min}$ of incubation at which time they became indistinguishable from the FDA+ category, which had been slowly losing green fluorescence. The FDA++ cells maintained a steady level of green fluorescence throughout the incubation. The cell concentration throughout the 2 hour stain incubation period did not stay constant (Figure 21b). There was a steep decline in the cell concentration in the FDA++ category within the first $20 \min \left(3.5 \times 10^{4}\right.$ cells ml $^{-1}$ to $2.5 \times 10^{4} \mathrm{cells} \mathrm{ml}^{-1}$ ) that continued throughout the incubation, and at the end of 2 hours the total cell concentration was $35 \%$ of the initial concentration. Neither cell concentration nor calculated fraction in each category significantly changed during the 


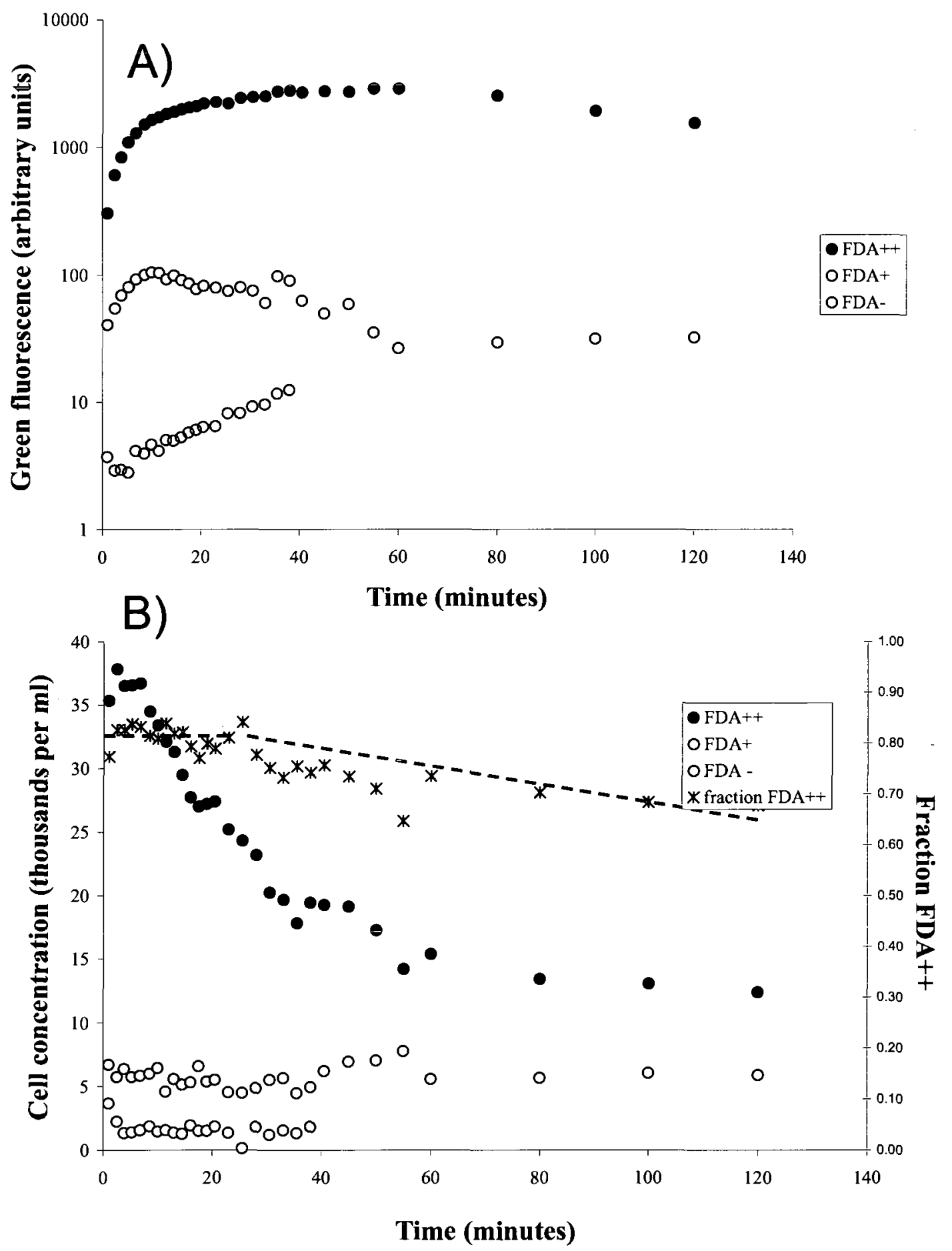

Figure 21. Optimal FDA stain time for small cryptophytes. A) Average green fluorescence of the three distinct metabolic categories over a two hour time period. B) Cell concentration of the three distinct metabolic responses over the two hour incubation shown with the calculated fraction FDA++. 
first 10 min of incubation, and since stain uptake and conversion were rapid, an incubation time of 3-7 min was deemed suitable for vital analysis of environmental phytoplankton.

\section{Environmental viability patterns}

Small cryptophyte viability was measured with fluorescein diacetate (FDA) at all ten stations where cell concentrations were high enough to be detected. All three metabolic responses (FDA++, FDA+, FDA-) were quantified at each station (Figure 22). Generally, the highly active fraction was higher at the inland stations. The pattern in viability was not necessarily correlated with abundance. For example, on cruise 155 the abundance of cells peaked at station 8 and decreased at stations 9 and 10 while the fraction FDA++ steadily increased up to station 10 (Figure 22 D, I). High fractions of FDA++ (or viable) are sometimes observed in the lower slough, but the highest fractions observed within a single cruise are always observed in the upper slough region as is seen when the fraction FDA++ is normalized to the maximum value within a cruise (Figure 23) . 


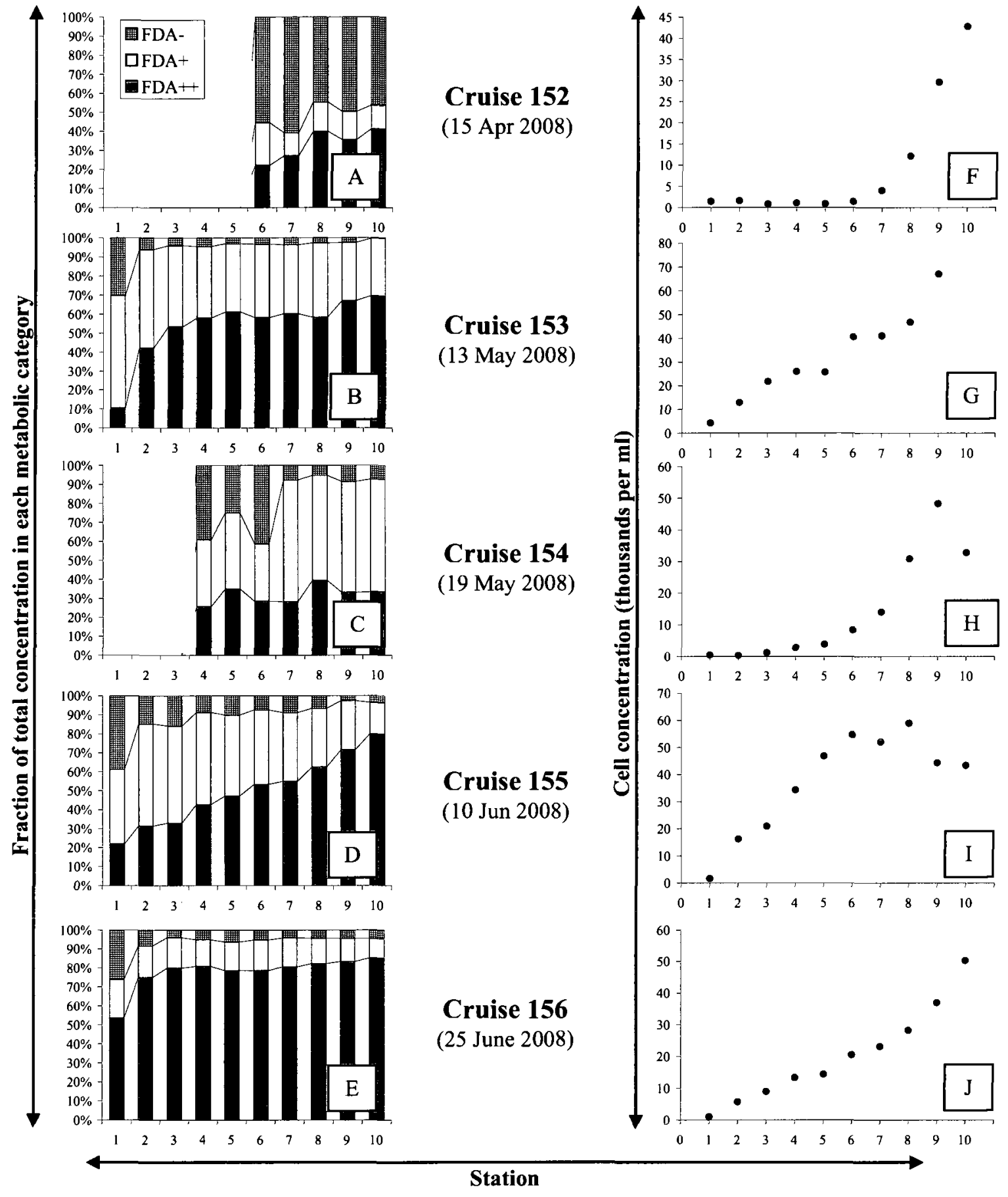

Figure 22. Fraction of EIkhorn Slough small cryptophytes in three FDA response categories (A-E) and corresponding cell concentrations (F-J) for ten stations in Elkhorn Slough on five sampling dates. Missing data is the result of cell concentrations too low to accurately determine viability. 


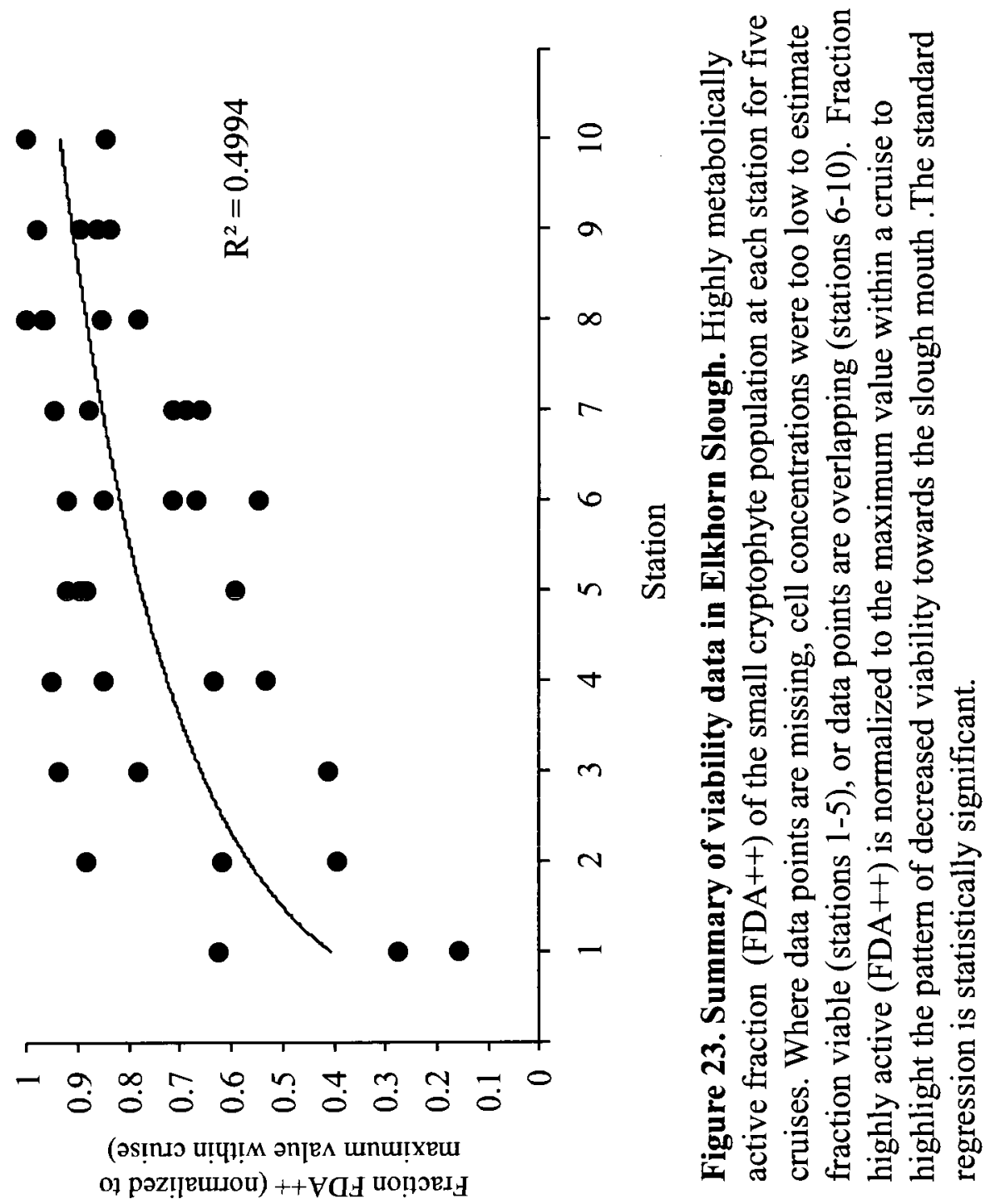




\section{DISCUSSION}

\section{Phytoplankton community structure of upper Elkhorn Slough}

Flow cytometric and size fractionation analyses reveal that the upper Elkhorn Slough is constitutively dominated by small $(<5 \mu \mathrm{m})$ cryptophytes and picophytoplankton. Large cryptophyte cells $(8-12 \mu \mathrm{m})$ are periodically abundant in Elkhorn Slough, though not persistent; it was therefore concluded they were not a major constituent of the upper slough phytoplankton community. At times large cells may constitute a significant fraction of the biomass, however during the spring and early summer, small cells $(<5 \mu \mathrm{m})$ made up over $85 \%$ of the chlorophyll $a(\mathrm{Chl} a)$ biomass.

It was unexpected to find small cells $(<5 \mu \mathrm{m})$ dominating the Chl $a$ biomass of a resource rich environment such as Elkhorn Slough. In coastal environments, estimates of the small phytoplankton contribution (1-8 $\mu \mathrm{m})$ to total $\mathrm{Chl} a$ biomass range from $5-40 \%$ (Iriarte 1993, Gin et al. 2000). Small phytoplankton size classes are more often considered to important constituents of the open ocean, oligotrophic environments than they are of nutrient-rich coastal environments (Irwin et al. 2006). The success of small cells in these environments is largely attributed to their characteristic high surface area to volume ratios resulting in higher rates of nutrient uptake as well as lower minimum metabolic requirements (Eppley and Thomas 1969, Grover 1991). These features allow them to thrive in low nutrient environments where large cells cannot.

This paradigm does not explain why small cells dominate the nutrient-rich environment of Elkhorn Slough. There are several other potential physiological and 
ecological consequences of cell size beyond inorganic nutrient acquisition and metabolic activity. Cell size has implications for light absorption, motility, susceptibility to grazing and sinking, and perhaps for dissolved organic nutrient uptake (Finkel 2001, Finkel et al. 2004, De Troch et al. 2006, Waite et al. 1997, Sommer 1988). The upper slough dissolved organic matter (DOM) concentrations are on average 7 times higher than what is found in the lower slough. The correlation between the upper slough phytoplankton population abundance and the DOM pattern suggests that DOM availability may play an important role in structuring the observed phytoplankton gradient. Whether DOM availability has a direct or indirect role in structuring this community is unclear.

Large cryptophytes $(8-12 \mu \mathrm{m})$ are periodically abundant in the upper Elkhorn Slough and are thought to live mixotrophically, doing performing photosynthetically with pigments adapted for low light levels and phagotrophically ingesting bacterial cells (Bergmann 2004). In this way, the large cryptophytes may benefit indirectly through high DOM levels. The small cryptophytes or picoeukaryotes found to be constitutively important in the upper Elkhorn Slough may survive on DOM as osmotrophs for which small cell size may confer an ecological advantage (Bergmann 2004).

Phytoplankton community structures characterized by omnipresent small cryptophytes and periodically appearing large cryptophyte cells have been documented in lakes where it is suggested that the small cells may be important for organic matter cycling (Somner 1987, Rott 1988). Furthermore, a small cryptophyte-microflagellate community complex was documented to increase in abundance during periods of decomposition (e.g., following a bloom) and was suggested to act as an internally 
stabilizing component of the planktonic community (Stewart and Wetzel 1986). These findings, along with the documented pattern in DOM suggest that the Elkhorn Slough small cryptophytes and picoeukaryotes may inhabit a similar ecological niche, and may be osmotrophic.

There are no consistent patterns in available nitrate temperature, salinity and light availability throughout the slough (Welschmeyer \& Younan unpubl). Therefore these parameters likely play a minor role if any in structuring the phytoplankton community. Though it was determined that the slough is not light-limited, the spectral characteristics of the available light were not characterized. This may potentially be an important structuring force for all upper slough phytoplankton communities with implications for trophic strategies (photosynthetic activity vs. heterotrophic metabolism).

The function of aquatic ecosystems is strongly influenced by the size structure of phytoplankton communities (Irwin et al. 2006). Trophic structure is affected by primary producer cell size since large phytoplankton are generally grazed by zooplankton and pass energy to higher trophic levels more efficiently than small cells which are grazed by protists and direct energy towards the microbial loop (Ryther 1969, Azam 1983). Understanding which forces structure the natural communities of the upper Elkhorn Slough will help to predict how perturbations to this system (such as erosion) will affect the phytoplankton and subsequently their effects on elemental cycling and trophic structure. 


\section{Analysis of viability in natural samples: Assay selection and significance}

The three vital assays chosen for this study, SYTOX Green, cell digestion and fluorescein diacetate (FDA), were selected because they have been used to estimate viability in natural phytoplankton populations (Veldhuis et al. 2001, Agustí and Sánchez 2002). Out of these three vital assays tested, only FDA was determined to be suitable assay to measure viability of the small cryptophyte population.

SYTOX Green performed well in experiments with known fractions of live and killed phytoplankton as verified by photosynthetic activity (Figure 15). However, in realistic scenarios of cell death such as nutrient limitation during culture senescence interpretation of staining patterns was difficult. In senescent cultures there is a gradient in cell morphology where the distinction between intact and degraded cells is no longer clear leading to difficulty in interpreting cytometric data. Additionally, DNA degradation in senescent cells can lead to reduced DNA fluorescence and variable staining that can be difficult to interpret (Lebaron et al. 1998). Therefore while interpreting SYTOX Green data in controlled and intact fractions of live and dead cells is straightforward, it cannot be expected that cell death scenarios encountered in nature would be this uncomplicated. Finally, SYTOX Green performed poorly in turbid samples where non-specific background staining was high and made detection of the target cells impossible. This is likely due to the polarity of the molecule and the affinity of the stain for charged particles regardless of DNA content (Klauth et al. 2004).

Environmental estimates of cell viability with SYTOX Green were obtained using samples from the oligotrophic ocean where terrigenous particulate matter loading would 
be less problematic than was experienced in this study (Veldhuis 2001). Therefore, under certain circumstances, SYTOX Green seems to be a robust and accurate measure of cell viability. However drawbacks such as difficulty interpreting complex staining patterns, ambiguous significance of membrane permeability in defining cell death and problems associated with non-specific background staining make it unsuitable for use in natural environments such as Elkhorn Slough.

The cell digestion assay is the most frequently used vital assay in field studies of phytoplankton viability (Figure 1). It has several advantages over stains including elimination of background staining, ambiguities in data interpretation and allows for the possibility of sample fixation rather than requiring analysis of live samples. The cell digestion assay may be suitable for many cell types and seemed to work reasonably well for the chlorophyte and diatoms tested in this study. However the $37^{\circ} \mathrm{C}$ incubation alone (no enzymes) caused an increase in orange fluorescence of laboratory cryptophyte cultures and dramatically reduced cell counts of natural populations making this method unsuitable for obtaining viability estimates in this study. It is possible that modifications to this method, such as altered incubation time and enzyme concentrations may ultimately render this method useful in this system, but the method as published was determined to be inappropriate for these target populations in Elkhorn Slough (Agustí and Sánchez 2002).

FDA was the most suitable fluorophore tested for vital analysis in the Elkhorn Slough environmental populations. There were no issues with background staining and discrimination of three distinct fluorescence responses (FDA++, FDA+, FDA-) was 
detected in the target cryptophyte population (Figure 22). In this system, a short (3-7 min) incubation was found to be ideal since this was found to both minimize potentially negative effects of the stain on cell concentration and to maximize discrimination of the three distinct FDA fluorescence responses.

The FDA assay is considered a valid assay of metabolic activity and thus vitality in phytoplankton. The non-fluorescent FDA substrate readily permeates cell membranes and is hydrolyzed by non-specific esterase enzymes into fluorescein. This fluorescein is then retained and can be detected by cells with intact cell membranes, but leaks from cells with compromised membranes (Rotman and Papermaster 1966). This assay has been shown to work with a variety of algal types and has been verified against measures of metabolic activity like ${ }^{14} \mathrm{C}$ photosynthesis (Dorsey et al. 1989, Onji et al. 2000). However, variability in the stain response has been reported for a variety of microorganisms and may be a function of inter- or intra-specific variability in factors such as cell wall structure, internal $\mathrm{pH}$, temperature, uptake kinetics, efflux rate, fluorescence quenching (Diaper et al. 1992, Breeuwer et al. 1995). Therefore, interpreting FDA data in environmental samples is not straightforward. It is for these reasons that FDA and other vital stains have not been routinely employed in ecological studies of microorganisms (Garvey et al. 2007).

Despite the potential drawbacks of all vital assays, there are several studies that suggest FDA is a valid indicator for general metabolic activity. It has been proposed that the degree of fluorescein accumulation is indicative of the strength of metabolic vigor (Bentley-Mowat 1982, Geary et al. 1998). Furthermore, the FDA assay is sensitive 
enough to reflect metabolic shifts in phytoplankton populations experiencing subtle environmental differences in light, nutrient regime, or other stressors (Jochem 1999, Brookes et al. 2000b).

Assays of intracellular enzyme activity can be a more sensitive indicator of death than assays of membrane integrity, since a decline in metabolic activity is thought to precede permeabilization of the cell membrane during the cell death process (Brussaard et al. 2001). When interpreting viability data, it is important to consider however that the degree of fluorescein accumulation reflects both the level of intracellular enzyme activity and the degree of fluorescein efflux due to membrane permeability (Rotman and Papermaster 1966, Breeuwer et al. 1995).

In Elkhorn Slough, the small cryptophyte population exhibited three distinct fluorescence responses characterized by no increase of green fluorescence (FDA-), a moderate (10-fold) increase in green fluorescence (FDA + ) and large (100-fold) increase in green fluorescence (Figure 20). The FDA++ group of small cryptophytes was interpreted to be highly metabolically active as they rapidly became fluorescent and sustained a high degree of fluorescence throughout the incubation period (Figure 21). Curiously, the cell concentrations of this highly active fraction declined dramatically within the first 40 min of the incubation and continued to decline throughout the 2 hour period. It is possible that cell lysis is an artifact of high fluorescein loading. Nonetheless, the cell losses within the first 3-7 min were negligible and it was possible to obtain an estimate of highly active cells prior to the onset of cell concentration loss. 
The FDA- group was determined to have no or low metabolic activity. Over the course of the incubation, some increased green fluorescence of this group was noted and was concluded to be the result of very low metabolic activity. After $40 \mathrm{~min}$, the fluorescence of this group was indistinguishable from the fluorescence of the moderate fluorescence $(\mathrm{FDA}+)$ group. Initially, the FDA+ group displays a 10-fold increase in fluorescence relative to the control but begins to lose fluorescence after approximately 15 min. This suggests that though these cells maintain elevated esterase activity relative to the FDA- group, they may have some permeability of the cell membrane allowing for efflux of the fluorescein product.

The tri-modal metabolic response observed for a single population is interesting and could be attributed to a variety of factors (Figure 20). First, it cannot be excluded that the single group designated as small cryptophytes may actually consist of several groups displaying individual FDA stain characteristics. The degree of population heterogeneity could be determined by flow-sorting this population of interest and characterizing its diversity with microscopy or molecular techniques (18S sequence diversity). However, without the capability to conduct these types of analyses, it was assumed that the population was taxonomically homogenous.

If the target population is taxonomically homogeneous as assumed, the tri-modal esterase activity response may be reflective of a step-wise regulation of metabolic activity, perhaps as the result of a programmed metabolic cascade. The observation of three discrete metabolic activity levels is not unprecedented in phytoplankton. Regel et al. (2002) characterized three metabolic (FDA) activity states in cultures of cyanobacteria 
and green algae. Metabolism may be regulated in a step-wise fashion to allow coordination or synchronization with other members of a given population. It has been shown that some phytoplankton (diatoms) possess a cellular mechanism allowing them to detect chemical signals originating from stressed neighbor cells which ultimately affects their physiology and subsequent population dynamics (Vardi et al. 2006). The extent to which these types of strategies persist and their functional role in populations of unicellular organisms is unclear though it has been speculated that it is likely more important than previously acknowledged (Bidle \& Falkowski 2004). Further characterizing natural patterns in population viability (or metabolic activity) such as the pattern characterized in this study will be instrumental in understanding the physiology, ecology, population dynamics and evolution of microorganisms in nature.

Vital assays such as FDA, cell digestion and SYTOX Green measure proxies for cell viability such as enzyme activity and membrane permeability, but the validity of these proxies as true indicators of a definite live or dead state is unclear. For example, phytoplankton cells exposed to copper do not exhibit esterase enzyme activity, yet upon restoration to ideal conditions, esterase enzyme activity resumes (Vasconcelos et al. 2000). In this scenario, the cells are not dead but are temporarily metabolically inactive. Also, SYTOX Green is expected to be excluded from cells with intact membranes and it is generally assumed that membrane permeability is a valid proxy for cellular death, yet it was observed in this study that some cells in batch culture stained "dead" with SYTOX Green yet simultaneously maintained metabolic activity as determined with FDA (Roth et al. 1997, Veldhuis et al. 1997, Veldhuis et al. 2001, personal observation). Furthermore, 
motile (and therefore live) cells have been reported to stain with SYTOX Green indicating that the assumption that membrane permeability is an accurate proxy for cellular death may be incorrect (Franklin and Berges 2004). While the utility of these vital assay proxies as absolute indicators of live or dead status is unclear, it is certain that they are useful indicators of general in-situ physiological status.

In conclusion, robust assays that work in complex and unpredictable environments must be identified to successfully obtain estimates of natural population viability. In Elkhorn Slough, the FDA assay proved to be free from issues with background staining that rendered SYTOX Green inappropriate. Interpreting the significance of these natural population viability estimates is less straightforward. Ideally, the natural population of interest would be isolated in culture so that experimental conditions can be controlled, and estimates of viability verified with other known measures of metabolic activity such as photosynthesis. However, few microorganisms in nature are amenable to cultivation, nor is a cultured strain representative of the physiology expected in nature. Therefore, investigating patterns of viability in natural populations may work to inform our interpretation of the significance of these results.

\section{Vitality of phytoplankton in Elkhorn Slough}

There are few published studies that have addressed whether dead, dying or metabolically compromised phytoplankton comprise a significant fraction of phytoplankton communities in nature (Table 2). The amount of dead cells at a given time 
in nature can be highly variable, for example the percentage of non-viable cells within a given population ranged from $5-60 \%$ in the North Atlantic as determined with SYTOX Green (Veldhuis et al. 2001). Understanding the significance of phytoplankton viability requires putting this variability into context. Hayakawa et al. (2008) reported viabilities of $>70 \%$ for eukaryotic phytoplankton in the spring, a season in which these phytoplankton were numerically dominant. The viability of these cells decreased to 26$41 \%$ by the late summer when they were no longer dominant. These data suggest that these cells were structured by forces causing physiological stress, a trend that may have been predicted by abundance data alone. In contrast, Synechococcus surveyed during these seasons exhibited major abundance changes, but the viability of the remaining cells remained high suggesting these cells are not physiologically compromised under conditions of low abundance.

Investigating the relationship between cell abundance and viability informs how a given population is responding to the conditions at that moment. Based on abundance alone, Hayakawa et al. (2008) may have erroneously concluded that Synechococcus was stressed or physiologically compromised during the spring when they were sparse.

In Elkhorn Slough it was hypothesized that the environment in the upper reaches is ideal for cryptophyte growth and was where they were expected to be most vital or active. The highest fraction of highly active cells within a given sampling date was indeed on average observed in the ideal upper slough environment (Figure 23). This finding suggests that the upper slough phytoplankton community is structured by environmental forces such as light quality or DOM and that deviation from these 
conditions towards the lower slough causes stress, reduced activity and subsequently death. However, cell abundance and viability were not always well correlated.

As previously discussed, it cannot be assumed that high population abundance is necessarily indicative of healthy cells. For example, during analysis of samples collected from cruise 155 it was observed that small cryptophyte densities peaked at station 8 and then declined at stations 9 and 10 whereas the fraction of the population that was highly metabolically active continued to increase to nearly $80 \%$ (Figure 22). Though cells at these stations are active and presumably growing quickly, this is not reflected in the total abundance. This could be attributed to heightened grazing pressure at these stations.

In summary, characterizing the in-situ physiological state of individual cells within specific populations with high spatial or temporal resolution is valuable when trying to understand how phytoplankton communities are structured in response to their physical environment and how their dynamics influence biogeochemistry and trophic structure. There is no single ideal assay to measure viability of phytoplankton or any natural unicellular microorganism and any investigation of natural microorganism viability must take both methodological and technical considerations into account. Significant consideration must be given to the design of the sampling scheme. Virtually all studies conducted on natural phytoplankton assemblage viability exploit welldocumented community structure transitions such as the spatial transition from the oligotrophic open ocean to the eutrophic coastal zone or the temporal transition from summer to winter communities (Alonso-Laita and Agustí 2006, Hayakawa et al. 2006). 
The Elkhorn Slough provided an ideal and accessible environment to examine how patterns in physiological state may structure the abundant and persistent population of small cryptophyte algae. 


\section{REFERENCES}

Abalde, J., A. Cid, S. Reiriz, E. Torres, and C. Herrero. 1995. Response of the marine microalga Dunaliella tertiolecta (Chlorophyceae) to copper toxicity in short time experiments. Bull. Environ. Contam. Toxicol. 54: 317-324.

Agustí, S., M. P. Satta, M. P. Mura, and E. Benavent. 1998. Dissolved esterase activity as a tracer of phytoplankton lysis: Evidence of high phytoplankton lysis rates in the northwestern Mediterranean. Limnol. Oceanogr. 43: 1836-1849.

Agustí, S., and M. C. Sánchez. 2002. Cell viability in natural phytoplankton communities quantified by a membrane permeability probe. Limnol. Oceanogr. 47: 818-828.

Agustí, S. 2004. Viability and niche segregation of Prochlorococcus and Synechococcus cells across the central Atlantic Ocean. Aquat. Microb. Ecol. 36: 53-59.

Agustí, S, E. Alou, M. V. Hoyer, T. K. Frazer, and D. E. Canfield. 2006. Cell death in lake phytoplankton communities. Freshwater Biol. 51: 1496-1506.

Alonso-Laita, P., and S. Agustí. 2006. Contrasting patterns of phytoplankton viability in the subtropical NE Atlantic Ocean. Aquat. Microb. Ecol. 43: 67-78.

Anderson, J. T., D. K. Stoecker, and R. R. Hood. 2003. Formation of two types of cysts by a mixotrophic dinoflagellate, Pfiesteria piscicida. Mar. Ecol. Prog. Ser. 246: 95-104.

Arsenault, G., A. D. Cvetkovic, and R. Popovic. 1993. Toxic effects of copper on Selenastrum capricornutum measured by a flow cytometry-based method. Water Pollut. Res. J. Can. 28: 757-765.

Azam, F., T. Fenchel, J. G. Field, J. S. Gray, L. A. Meyer-Reil, and F. Thingstad. 1983. The ecological role of water-column microbes in the sea. Mar. Ecol. Prog. Ser. 10: $257-263$.

Bidle, K. D., and P. G. Falkowski. 2004. Cell death in planktonic, photosynthetic microorganisms. Nat. Rev. Microbiol. 2: 643-655.

Binet, M. T., and J. L. Stauber. 2006. Rapid flow cytometric method for the assessment of toxic dinoflagellate cyst viability. Mar. Environ. Res. 62: 247-260.

Bentley-Mowat, J. A. 1982. Application of fluorescence microscopy to pollution studies on marine phytoplankton. Bot. Mar. 25: 203-204. 
Berdalet, E., and Q. Dortch. 1991. New double-staining technique for RNA and DNA measurement in marine phytoplankton. Mar. Ecol. Prog. Ser. 73: 295-305.

Berges, J. A., and P. G. Falkowski. 1998. Physiological stress and cell death in marine phytoplankton: Induction of proteases in response to nitrogen or light limitation. Limnol. Oceanogr. 43: 129-135.

Berglund, D. L., and S. Eversman. 1988. Flow cytometric measurement of pollutant stresses on algal cells. Cytometry. 9: 150-155.

Bergmann, T. I. 2004. The physiological ecology and natural distribution patterns of cryptomonad algae in coastal aquatic ecosystems. Ph.D. thesis. Rutgers.

Berman-Frank, I., K. D. Bidle, L. Haramaty, and P. G. Falkowski. 2004. The demise of the marine cyanobacterium, Trichodesmium spp., via an autocatalyzed cell death pathway. Limnol. Oceanogr. 49: 997-1005.

Breeuwer, P., J. L. Drocourt, N. Bunschoten, M. H. Zwietering, F. M. Rombouts, T. Abee (1995). Characterization of uptake and hydrolysis of fluorescein diacetate and carboxyfluorescein diacetate by intracellular esterases in Saccharomyces cerevisiae, which result in accumulation of fluorescent product. Appl. Environ. Microbiol. 61: 1614-1619.

Brookes, J. D., G. G. Ganf, R. L. Oliver. 2000a. Heterogeneity of cyanobacterial gasvesicle volume and metabolic activity. J. Plank. Res. 22: 1579-1589.

Brookes, J. D., S. M. Geary, G. G. Ganf, M. D. Burch. 2000b. The use of FDA and flow cytometry to assess metabolic activity as an indicator of nutrient status in phytoplankton. Mar. Freshwater Res. 51: 817-823.

Brussaard, C. P. D., D. Marie, R. Thyrhaug, and G. Bratbak. 2001. Flow cytometric analysis of phytoplankton viability following viral infection. Aquat. Microb. Ecol. 26: $157-166$.

Button, D. K., R. Schut, P. Quang, R. Martin, and B.R. Robertson. 1993. Viability and isolation of marine bacteria by dilution culture: Theory, procedures and initial results. Appl. Environ. Microbiol. 59: 881-891.

Casotti, R., S. Mazza, C. Brunet, V. Vantrepotte, A. Ianora, and A. Miralto. 2005. Growth inhibition and toxicity of the diatom aldehyde 2-trans,4-trans-decadienal on Thalassisira weissflogii (Bacillariophyceae). J. Phycol. 41: 7-20.

Cerino, F. and A. Zingone. 2007. Decrypting cryptomonads: a challenge for molecular taxonomy. In J. Brodie and J. Lewis [eds.], Unravelling the algae: The past, present and future of algal systematics. CRC Press. 
Chisholm, S. W., R. J. Olson, E. R. Zettler, R. Goericke, J. B. Waterbury, and N. A. Welschmeyer. 1988. A novel free-living prochlorophyte abundant in the oceanic euphotic zone. Nature. 334: 340-343.

Coble, P. G. 1996. Characterization of marine and terrestrial DOM in seawater using excitation - emission matrix spectroscopy. Mar. Chem. 51: 325-346.

Collier, J. L. 2000. Flow cytometry and the single cell in phycology. J. Phycol. 36: 628644.

Connon, S. A., and S. J. Giovannoni. 2002. High-throughput methods for culturing microorganisms in very-low-nutrient media yield diverse new marine isolates. Appl. Env. Microbiol. 68: 3878-3885.

Crippen, R. W., and J. L. Perrier. 1974. The use of neutral red and Evans blue for livedead determinations of marine plankton. Stain Technol. 49: 97-103.

Darzynkiewicz, Z., X. Li, and J. Gong. 1994. Assays of cell viability: Discrimination of cells dying by apoptosis. In Z. Darzynkiewicz, J. P. Robinson, and H. A. Crissman [eds.], Methods in cell biology. Academic.

De Troch, M., V. Chepurnov, H. Gheerardyn, A. Vanreusel, and E. Olafsson. 2006. Is diatom size selection by harpactacoid copepods related to grazer body size? J. Exp. Mar. Biol. Ecol. 332: 1-11.

Descolas-Gros, C. 1980. Use of track autoradiography in oceanography: Evaluation of phytoplankton species productivity. J. Plankton Res. 2: 23-32.

Diaper, J. P., K. Tither, and C. Edwards. 1992. Rapid assessment of bacterial viability by flow cytometry. Appl. Microbiol. And Biotechnol. 38: 268-272.

Dorsey, J., C. M. Yentsch, S. Mayo, and C. McKenna. 1989. Rapid analytical technique for the assessment of cell metabolic activity in marine microalgae. Cytometry. 10: 622-628.

Eppley, R. W., and W. H. Thomas. 1969. Comparison of half-saturation constants for growth and nitrate uptake of marine phytoplankton. J. Phycol, 5: 374-379.

Faber, M. J., L. M. J. Smith, H. J. Boermans, G. R. Stephenson, D. G. Thompson, and K. R. Solomon. Cryopreservation of fluorescent marker-labeled algae (Selenastrum capricornutum) for toxicity testing using flow cytometry. Environ. Toxicol. Chem. 16: 1059-1067. 
Faust, M. A., and D. L. Correll. 1977. Autoradiographic study to detect metabolically active phytoplankton and bacteria in the Rhode River estuary. Mar. Biol. 41: 293305.

Finkel, Z. V. 2001. Light absorption and size scaling of light-limited metabolism in marine diatoms. Limnol. Oceanogr. 46: 86-94.

Finkel, Z. V., A. J. Irwin, and O. Schofield. 2004. Resource limitation alters the $3 / 4$ size scaling of metabolic rates in phytoplankton. Mar. Ecol. Prog. Ser. 273: 269-279.

Franklin, D. J., C. P. D. Brussaard, and J. A. Berges. 2006. What is the role and nature of programmed cell death in phytoplankton ecology? Eur. J. Phycol. 41: 1-14.

Franklin, D. J., C. M. M. Cedrés, and O. Hoegh-Guldberg. 2006. Increased mortality and photoinhibition in the symbiotic dinoflagellates of the Indo-Pacific coral Stylophora pistillata (Esper) after summer bleaching. Mar. Biol. 149: 633-642.

Franklin, D. J., and J. A. Berges. 2004. Mortality in cultures of the dinoflagellate Amphidinium carterae during culture senescence and darkness. Proc. R. Soc. Lond. B. 271: 2099-2107.

Franklin, D. J., O. Hoegh-Guldberg, R. J. Jones, and J. A. Berges. 2004. Cell death and degeneration in the symbiotic dinoflagellates of the coral Stylophora pistillata during bleaching. Mar. Ecol. Prog. Ser. 272: 117-130.

Franklin, N. M., M. S. Adams, J. L. Stauber, and R. P. Lim. 2001. Development of an improved rapid enzyme inhibition bioassay with marine and freshwater microalgae using flow cytometry. Arch. Environ. Contam. Toxicol. 40: 469-480.

Gala, W. R., and J. P. Giesy. 1994. Flow cytometric determination of the photoinduced toxicity of anthracene to the green alga Selenastrum capricornutum. Environ. Toxicol. Chem. 13: 831-840.

Gallagher, J. C. 1984. Patterns of cell viability in the diatom, Skeletonema costatum, in batch culture and in natural populations. Estuaries. 7: 98-101.

Garvey, M., B. Moriceau, and U. Passow. 2007. Applicability of the FDA assay to determine the viability of marine phytoplankton under different environmental conditions. Mar. Ecol. Prog. Ser. 352: 17-26.

Geary, S., G. Ganf, J. Brookes. 1997. The use of FDA and flow cytometry to measure the metabolic activity of the cyanobacteria, Microcystis aeruginosa. Verh. Int. Verein. Limnol. 4: 1-3. 
Gieskes, W., and G. Kraay. 1983. Dominance of Cryptophyceae during the phytoplankton spring bloom in the Central North Sea detected by HPLC analysis of pigments. Mar. Biol. 75: 179-185.

Gilbert, F., F. Galgani, and Y. Cadiou. 1992. Rapid assessment of metabolic activity in marine microalgae: Application in ecotoxicological tests and evaluation of water quality. Mar. Biol. 112: 199-205.

Gin, K. Y., X. Lin, and S. Zhang. 2000. Dynamics and size structure of phytoplankton in the coastal waters of Singapore. J. Plankton Res. 22: 1465-1484.

Goericke, R., and N. A. Welschmeyer. 1993. The carotenoid-labeling method: measuring specific rates of carotenoid synthesis in natural phytoplankton communities. Mar. Ecol. Prog. Ser. 98: 157-171.

Gregg, M. D., and G. M. Hallegraeff. 2007. Efficacy of three commercially available ballast water biocides against vegetative microalgae, dinoflagellate cysts and bacteria. Harmful Algae. 6: 567-584.

Grover, J. P. 1991. Resource competition in a variable environment: Phytoplankton growing according to the variable-internal-stores model. Am. Nat. 138: 811-835.

Hayakawa, M., K. Suzuki, H. Saito, K. Takahashi, and S. Ito. 2008. Differences in cell viabilities of phytoplankton between spring and late summer in the northwest Pacific Ocean. J. Exp. Mar. Biol. Ecol. 360: 63-70.

Holm, E. R., D. M. Stamper, R. A. Brizzolara, L. Barnes, N. Deamer and J. M. Burkholder. 2008. Sonication of bacteria, phytoplankton and zooplankton: Application to treatment of ballast water. Mar. Pollut. Bull. 56: 1201-1208.

Iriarte, A. 1993. Size-fractionated chlorophyll $a$ biomass and picophytoplankton cell density along a longitudinal axis of a temperate estuary (Southampton Water). J. Plankton Res. 15: 485-500.

Irwin, A. J., Z. V. Finkel, O. M. E. Schofield, and P. G. Falkowski. 2006. Scaling-up from nutrient physiology to the size-structure of phytoplankton communities. J. Plankton Res. 28: 459-471.

Jansen, S., and U. Bathmann. 2007. Algae viability within copepod faecal pellets: Evidence from microscopic examinations. Mar. Ecol. Prog. Ser. 337: 145-153.

Jochem, F. J. 1999. Dark survival strategies in marine phytoplankton assessed by cytometric measurement of metabolic activity with fluorescein diacetate. Mar. Biol. 135: 721-728. 
Joux, F., and P. Lebaron. 2000. Use of fluorescent probes to assess physiological functions of bacteria at single-cell level. Microb. Infect. 2: 1523-1535.

Kirchman, D. L. 1999. Phytoplankton death in the sea. Nature. 398: 293-204.

Klauth, P., R. Wilhelm, E. Klumpp, L. Poschen, and J. Groeneweg. 2004. Enumeration of soil bacteria with the green fluorescent nucleic acid dye Sytox green in the presence of soil particles. J. Microbiol. Meth. 59: 189-198.

Klaveness, D. 1989. Biology and ecology of the Cryptophyceae: Status and challenges. Biol. Oceanogr. 6: 257-270 .

Latour, D., O. Sabido, M. Saleçon, and H. Giraudet. 2004. Dynamics and metabolic activity of the benthic cyanobacterium Microcystis aeruginosa in the Grangent reservoir (France). J. Plankton Res. 26: 719-726.

Lawrence, J. E., C. P. D. Brussaard, and C. A. Suttle. 2006. Virus-specific responses of Heterosigma akashiwo to infection. Appl. Env. Microbiol. 72: 7829-7834.

Lebaron, P., P. Catala, and N. Parthuisot. 1998. Effectiveness of SYTOX Green stain for bacterial viability assessment. Appl. Environ. Microbiol. 64: 2697-2700.

Lee, D. Y., and G. Y. Rhee. 1997. Kinetics of cell death in the cyanobacterium Anabaena flos-aquae and the production of dissolved organic carbon. J. Phycol. 33: 991-998.

Lee, D. Y., and G. Y. Rhee. 1999. Kinetics of growth and death in Anabaena flos-aquae (Cyanobacteria) under light limitation and supersaturation. J. Phycol. 35: 700709 .

Legendre, L., C. Courties, and M. Troussellier. 2001. Flow cytometry in oceanography 1989 - 1999: Environmental challenges and research trends. Cytometry. 44: 164172.

Llabrés, M., and S. Agustí. 2006. Picophytoplankton cell death induced by UV radiation: Evidence for oceanic Atlantic communities. Limnol. Oceanogr. 51: 21-29.

Marie, D., N. Simon, and D. Vaulot. 2005. Phytoplankton cell counting by flow cytometry. In R. A. Andersen [ed.], Algal culturing techniques. Elsevier.

Minier, C., F. Galgani, and J. M. Robert. 1993. In vivo characterization of esterase activity in calothrix PCC 7601, Haslea ostrearia and Prorocentrum micans. Bot. Mar. 36: 245-252.

Moharikar, S., J. S. D'Souza, A. B. Kulkarni, and B. J. Rao. 2006. Apoptotic-like cell death pathway is induced in unicellular chlorophyte Chlamydomonas reinhardtii 
(Chlorophyceae) cells following UV irradiation: Detection and functional analyses. J. Phycol. 42: 423-433.

Murphy, A. M., and T. J. Cowles. 1997. Effects of darkness on multi-excitation in vivo fluorescence and survival in a marine diatom. Limnol. Oceanogr. 42: 1444-1453.

Nebe-von Caron, G., and R. A. Badley. 1995. Viability assessment of bacteria in mixed populations using flow cytometry. J. Microsc. 179: 55-66.

Okochi, M., T. Taguchi, M. Tsuboi, N. Nakamura, and T. Matsunaga. 1999. Fluorometric observation of viable and dead adhering diatoms using TO-PRO-1 iodide and its application to the estimation of electrochemical treatment. Appl. Microbiol. Biotechnol. 51: 364-369.

Onji, M., T. Sawabe, and Y. Ezura. 2000. An evaluation of viable staining dyes suitable for marine phytoplankton. Bull. Fac. Fish. Hokkaido Univ. 51: 153-157.

Paerl, H. W. 1978. Effectiveness of various counting methods in detecting viable phytoplankton. N. Z. J. Mar. Fresh. Res. 12: 67-72.

Peterson, B. J. 1980. Aquatic primary productivity and the ${ }^{14} \mathrm{C}-\mathrm{CO}_{2}$ method: A history of the productivity problem. Ann. Rev. Ecol. Syst. 11: 359-85.

Porter, J., D. Deere, M. Hardman, C. Edwards, and R. Pickup. 1997. Go with the flow use of flow cytometry in environmental microbiology. FEMS Microbiol. Ecol. 24: $93-101$.

Pouneva, I. 1997. Evaluation of algal culture viability and physiological state by fluorescence microscopic methods. Bulg. J. Plant Physiol. 23: 67-76.

Prince, E. K., T. L. Myers, and J. Kubanek. 2008. Effects of harmful algal blooms on competitors: Allelopathic mechanisms of the red tide dinoflagellate Karenia brevis. Limnol. Oceanogr. 53: 531-541.

Reiriz, S., C. Cid, E. Torres, J. Abalde, C. Herrero. 1994. Different responses of the marine diatom P. tricornutum to copper toxicity. Microbiología. 10: 263-272.

Regel, R. H. 1997. The response of Microcystis aeruginosa (Cyanophyceae) to heavy metals and stormwater. Honors thesis, University of Adelaide, SA, Australia.

Regel, R. H., J. M. Ferris, G. G. Ganf, and J. D. Brookes. 2002. Algal esterase activity as a biomeasure of environmental degradation in a freshwater creek. Aquat. Toxicol. 59: 209-223. 
Regel, R. H., J. D. Brookes, G. G. Ganf, R. W. Griffiths. 2004. The influence of experimentally generated turbulence on the Mash01 unicellular Microcystis aeruginosa strain. Hydrobiologia. 517: 107-120.

Reynolds, A. E., G. B. Mackiernan, and S. D. van Valkenburg. 1978. Vital and mortal staining of algae in the presence of chlorine-produced oxidants. Estuaries. 1: 192196.

Ribalet, F., J. A. Berges, A. Ianora, and R. Casotti. 2007. Growth inhibition of cultured marine phytoplankton by toxic algal-derived polyunsaturated aldehydes. Aquat. Toxicol. 85: 219-227.

Roth, B. L., M. Poot, S. T. Yue, and P. J. Millard. 1997. Bacterial viability and antibiotic susceptibility testing with SYTOX Green Nucleic Acid Stain. Appl. Environ. Microbiol. 63: 2421-2431.

Rotman, B., and B. W. Papermaster. 1966. Membrane properties of living mammalian cells as studied by enzymatic hydrolysis of fluorogenic esters. Proc. Nat. Acad. Sci. 55: 134-141.

Rott, E. 1988. Some aspects of the seasonal distribution of flagellates in mountain lakes. Hydrobiologia. 161: 203-209.

Rowe, R., R. Todd, and J. Waide. 1977. Microtechnique for most-probable-number analysis. Appl. Environ. Microbiol. 33: 675-680.

Ryther, J. H. 1969. Photosynthesis and fish production in the sea. Science. 166: 72-76.

Selvin, R., B. Reguera, I. Bravo, and C. M. Yentsch. 1988. Use of fluorescein diacetate (FDA) as a single-cell probe of metabolic activity in dinoflagellate cultures. Biol. Oceanogr. 6: 505-511.

Segovia, M., L. Haramaty, J. A. Berges, and P. G. Falkowski. 2003. Cell death in the unicellular chlorophyte Dunaliella tertiolecta. A hypothesis on the evolution on apoptosis in higher plants and metazoans. Plant Phys. 132: 99-105.

Sommer, U. 1987. Factors controlling the seasonal variation in phytoplankton species composition: A case study for a deep, nutrient rich lake. Progr. Phycol. Res. 5: 123-178.

Sommer, U. 1988. Some size relationships in phytoflagellate motility. Hydrobiologia 161: $125-131$. 
Staley, J. T., and A. Konopka. 1985. Measurement of in situ activities of nonphotosynthetic microorganisms in aquatic and terrestrial habitats. Ann. Rev. Microbiol. 39: 321-346.

Stewart, A. J., and R. G. Wetzel. 1986. Cryptophytes and other microflagellates as couplers in plankton community dynamics. Arch. Hydrobiol. 106: 1-19.

Timmermans, K. R., M. J. W. Veldhuis, and C. P. D. Brussaard. 2007. Cell death in three marine diatom species in response to different irradiance levels, silicate, or iron concentrations. Aquat. Microb. Ecol. 46: 253-261.

van de Poll, W., M. A. van Leeuwe, J. Roggeveld, and A. G. J. Buma. 2005. Nutrient limitation and high irradiance acclimation reduce PAR and UV-induced viability loss in the antarctic diatom Chaetocerous brevis (Bacillariophyceae). J. Phycol. 41: $840-850$.

van de Poll, W. H., A. Alderkamp, P. J. Janknegt, J. Roggeveld, and A. G. J. Buma. 2006. Photoacclimation modulates excessive photosynthetically active and ultraviolet radiation effects in a temperate and an Antarctic marine diatom. Limnol. Oceanogr. 51: 1239-1248.

Vardi, A., I. Berman-Frank, T. Rozenberg, O. Hadas, A. Kaplan, and A. Levine. 1999. Programmed cell death of the dinoflagellate Peridinium gatunense is mediated by $\mathrm{CO}_{2}$ limitation and oxidative stress. Curr. Biol. 9: 1061-1064.

Vardi, A., F. Formiggini, R. Casotti, A. De Martino, F. Ribalet, A. Miralto, and C. Bowler. 2006. A stress surveillance system based on calcium and nitric oxide in marine diatoms. PLOS Biol. 4: 411-419.

Vasconcelos, M. T. S. D., C. M. R. Almeida, O. M. Lage, and F. Sansonetty. 2000. Influence of zwitterionic $\mathrm{pH}$ buffers on the bioavailability and toxicity of copper to the alga Amphidinium carterae. Environ. Toxicol. Chem. 19: 2542-2550.

Veal, D. A., D. Deere, B. Ferrari, J. Piper, and P. V. Attfield. 2000. Fluorescence staining and flow cytometry for monitoring microbial cells. J. Immunol. Methods. 243: 191-210.

Veldhuis, M. J. W., T. L. Cucci, and M. E. Sieracki. 1997. Cellular DNA content of marine phytoplankton using two new fluorochromes: Taxonomic and ecological implications. J. Phycol. 33: 527-541.

Veldhuis, M. J. W., G. W. Kraay, and K. R. Timmermans. 2001. Cell death in phytoplankton: correlation between changes in membrane permeabiligy, photosynthetic activity, pigmentation and growth. Eur. J. Phycol. 36: 167-177. 
Waite, A., A. Fisher., P. A. Thomspon, and P. J. Harrison. 1997. Sinking rate versus cell volume relationships illuminate sinking rate control mechanisms in marine diatoms. Mar. Ecol. Prog. Ser. 157: 97-108.

Walsh, J. J. 1983. Death in the sea: Enigmatic phytoplankton losses. Prog. Oceanogr. 12: $1-86$.

Watt, W. D. 1971. Measuring primary production rates of individual phytoplankton species in natural mixed populations. Deep-sea Research. 18: 329-339.

Wigglesworth-Cooksey, B., K. E. Cooksey, and R. Long. 2006. Antibiotic from the marine environment with antimicrobial fouling activity. Env. Toxicol. 22: 275280.

Woomer, P., J. Bennett, and R. Yost. 1990. Overcoming the inflexibility of mostprobable-number procedures. Agron. J. 82: 349-353. 